\title{
Generation of Masked Till Intermediates from TiIV Amides via $\beta$-H Abstraction or Alkyne Deprotonation: an Example of Ti-Catalyzed Nitrene-Coupled Transfer Hydrogenation
}

Adam J. Pearce, Yukun Cheng, Rachel J. Dunscomb and Ian A. Tonks*

Contribution from the Department of Chemistry, University of Minnesota - Twin Cities, 207 Pleasant St SE, Minneapolis MN55455, United States.Email: itonks@umn.edu

\section{Supporting Information}

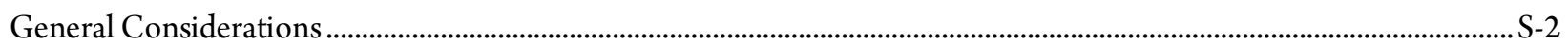

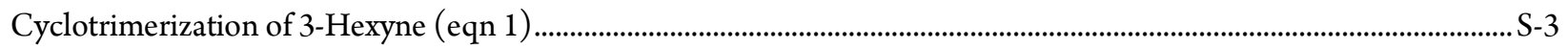

Hydroamination of 3-Hexyne with Azobenzene (eqn 2) ………................................................................................... S-5

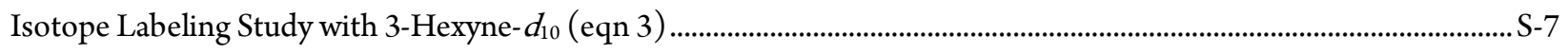

Isotope Labeling Study with 3-Hexyne- $d_{10}$ at $10 \%$ Catalyst Loading................................................................................

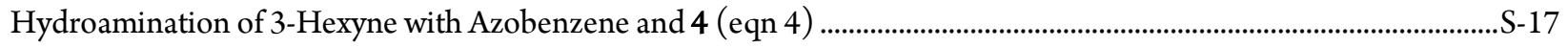

Transfer Hydrogenation of 4 to Azobenzene (eqn 5) ........................................................................................................

Transfer Hydrogenation of $\mathrm{TiCl}_{2}\left(\mathrm{NMe}_{2}\right)_{2}$ to Azobenzene...........................................................................................

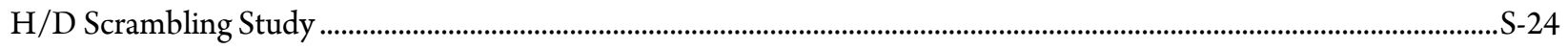

Plausible Mechanism of Transfer Hydrogenation of 4 to Azobenzene................................................................................

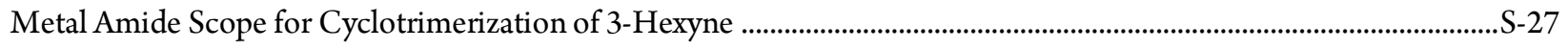

Metal Amide Scope for Hydroamination of 3-Hexyne with Azobenzene and 4 ..............................................................

References.... - 


\section{General Considerations}

All air- and moisture-sensitive compounds were manipulated in a glovebox under nitrogen atmosphere. $\mathrm{C}_{6} \mathrm{H}_{5} \mathrm{Br}$ was dried over $\mathrm{CaH}_{2}$ and distilled before passing through activated alumina and storing over activated $3 \AA$ molecular sieves in the glovebox. $\mathrm{C}_{6} \mathrm{D}_{5} \mathrm{Br}$ was synthesized following a reported procedure ${ }^{1}$ and passed through activated alumina before storing over activated $3 \AA$ molecular sieves in the glovebox. $\mathrm{Ti}\left(\mathrm{NMe}_{2}\right)_{4}{ }^{2,3}$ and $\mathrm{TiCl}_{2}\left(\mathrm{NMe}_{2}\right)_{2}{ }^{4}$ were synthesized following reported procedures. 3-Hexyne, 4 and $\mathrm{TiCl}_{4}$ were purchased from Millipore-Sigma. Azobenzene was purchased from TCI Chemicals and purified by hexane/water extraction three times. $\mathrm{Zr}\left(\mathrm{NMe}_{2}\right)_{4}, \mathrm{~V}\left(\mathrm{NMe}_{2}\right)_{4}, \mathrm{Ta}\left(\mathrm{NMe}_{2}\right)_{5}$ were purchased from Strem Chemicals. 3-Hexyne- $d_{10}$ was purchased from Cambridge Isotope Laboratories, Inc. ${ }^{1} \mathrm{H},{ }^{2} \mathrm{H}$, and COSY were collected on a Bruker Avance III HD NanoBay $400 \mathrm{MHz}$ spectrometer. ${ }^{1} \mathrm{H}$ NMR of catalytic reactions in $\mathrm{C}_{6} \mathrm{D}_{5} \mathrm{Br}$ were referenced to the proton signal of the internal standard 1,3,5-trimethoxybenzene (TMB, -OC $H_{3}, \mathrm{~s}, 3.51$ ppm). Mass spectra were collected on a Bruker BioTOF II ESI/TOF-MS spectrometer. 


\section{Cyclotrimerization of 3-Hexyne (eqn 1)}
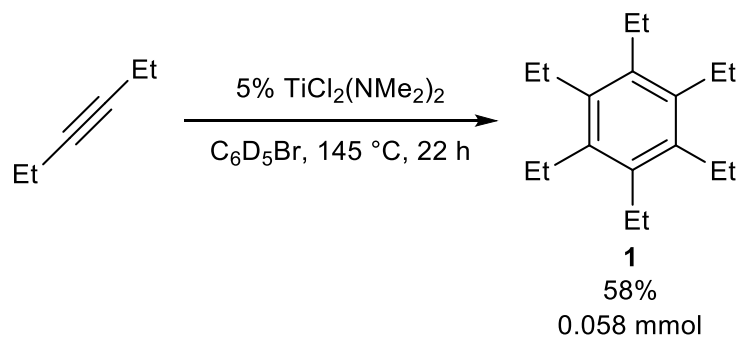

$\mathrm{TiCl}_{2}\left(\mathrm{NMe}_{2}\right)_{2}$ (3.1 mg, $0.015 \mathrm{mmol}, 0.05$ equiv), 3-hexyne ( $24.6 \mathrm{mg}, 0.3 \mathrm{mmol}, 1$ equiv), 1,3,5-trimethoxybenzene (5.0 $\mathrm{mg}, 0.03 \mathrm{mmol}, 0.1$ equiv, internal standard) and $0.5 \mathrm{~mL}$ of $\mathrm{C}_{6} \mathrm{D}_{5} \mathrm{Br}$ were added to a J-Young NMR tube. The reaction mixture was then sealed and heated in a preheated oil bath at $145^{\circ} \mathrm{C}$ for $22 \mathrm{~h} .{ }^{1} \mathrm{H}$ NMR spectra were collected before and after heating to monitor the reaction.
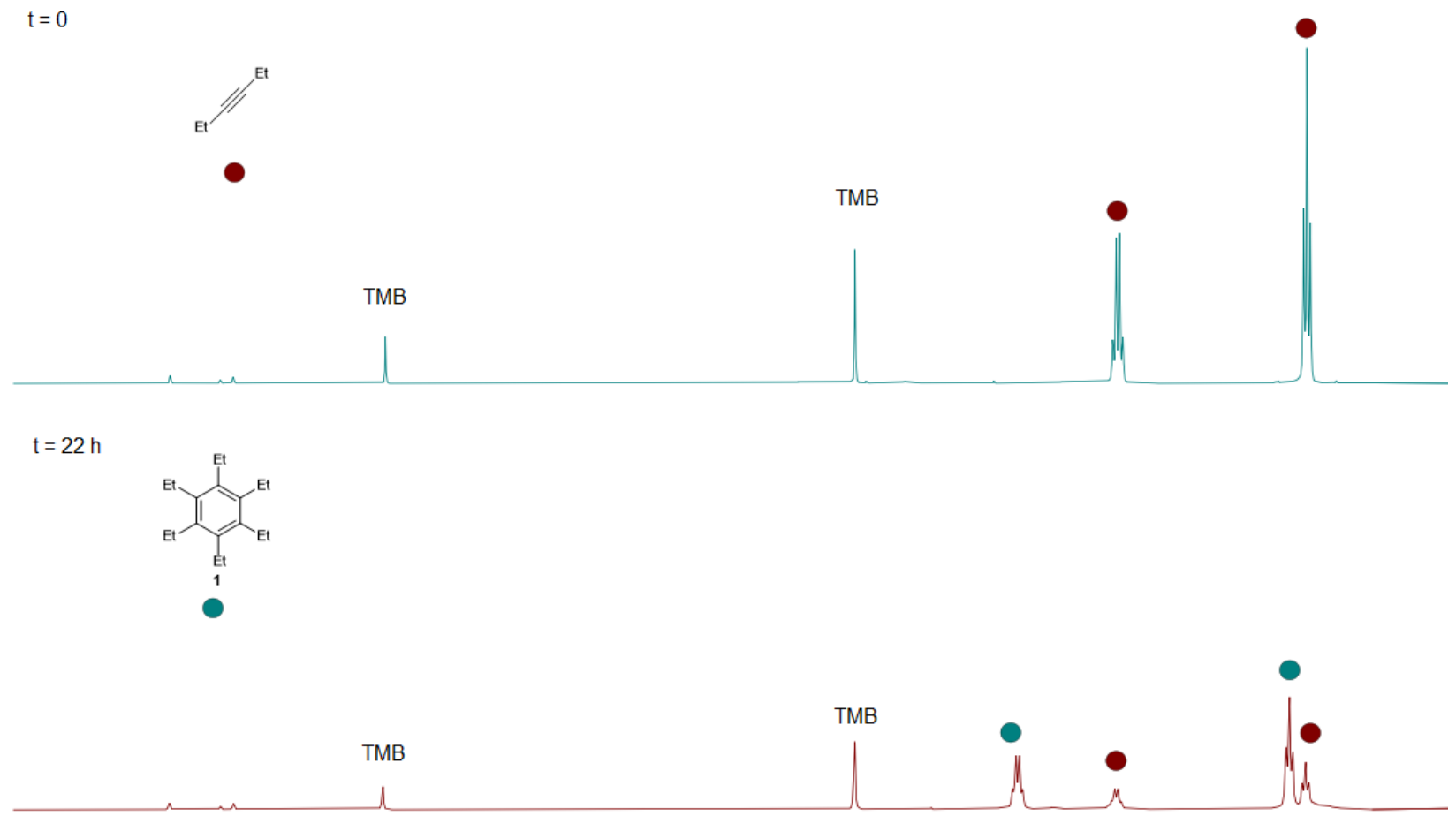

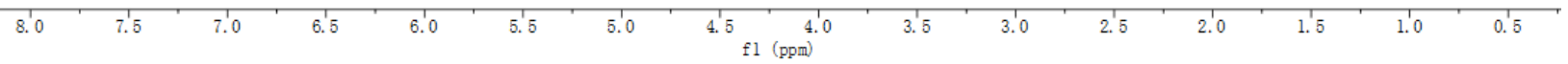

Figure S1. Stacked ${ }^{1} \mathrm{H}$ NMR spectra of $\mathrm{TiCl}_{2}\left(\mathrm{NMe}_{2}\right)_{2}$-catalyzed cyclotrimerization of 3-hexyne in $\mathrm{C}_{6} \mathrm{D}_{5} \mathrm{Br}$. Top: $\mathrm{t}=0$. Bottom: $\mathrm{t}=22 \mathrm{~h}$. 


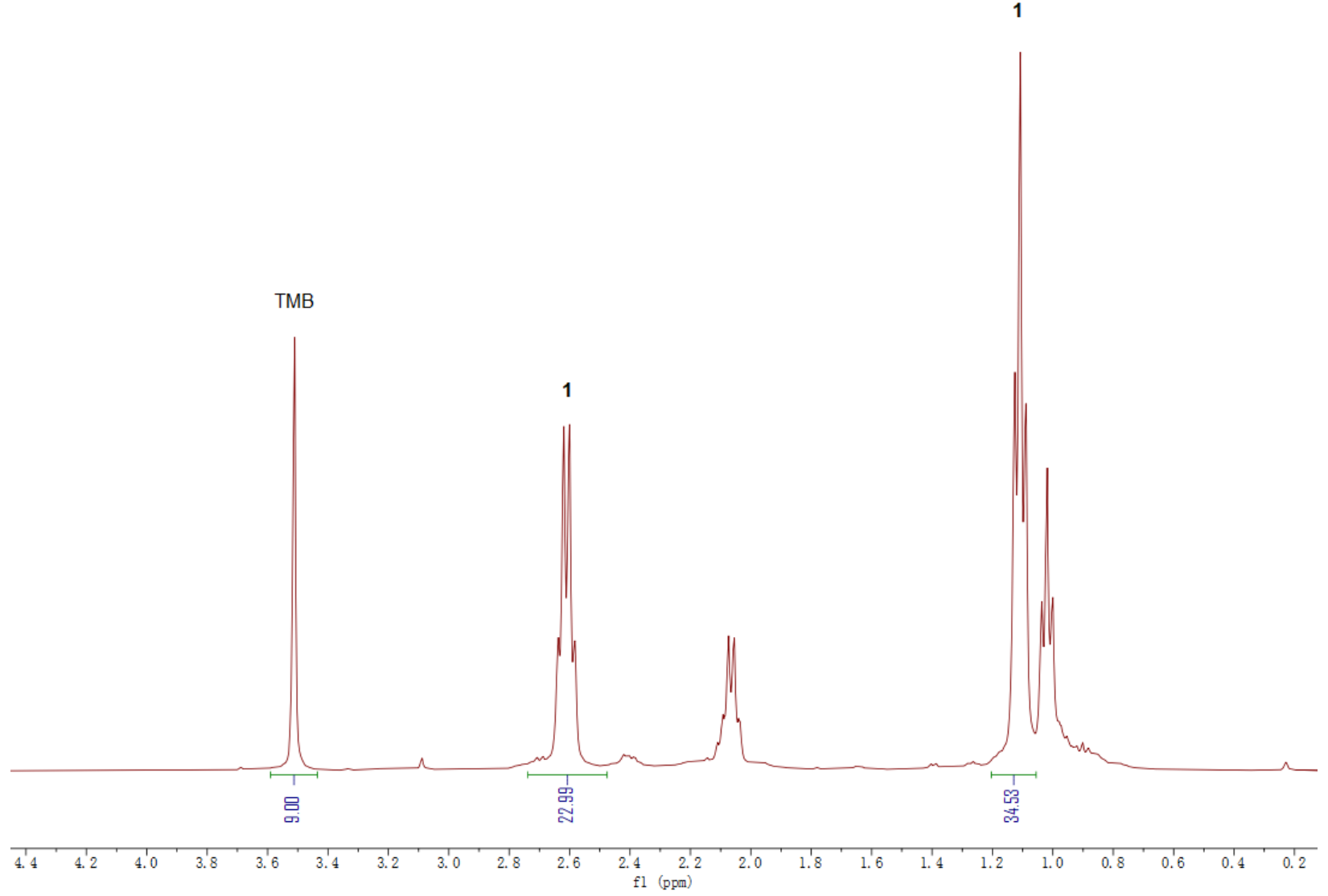

Figure S2. $\mathrm{t}=22 \mathrm{~h}{ }^{1} \mathrm{H}$ NMR spectrum of $\mathrm{TiCl}_{2}\left(\mathrm{NMe}_{2}\right)_{2}$-catalyzed cyclotrimerization of 3-hexyne in $\mathrm{C}_{6} \mathrm{D}_{5} \mathrm{Br}$ for yield calculation. 
Hydroamination of 3-Hexyne with Azobenzene (eqn 2)

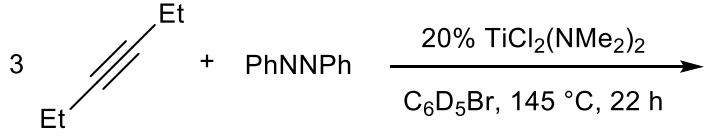

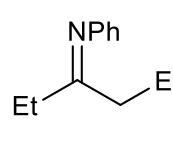

3

$62 \%$

$0.12 \mathrm{mmol}$<smiles>CCc1c(CC)c(CC)n(-c2ccccc2)c1CC</smiles>

2

$10 \%$

$0.020 \mathrm{mmol}$

$\mathrm{TiCl}_{2}\left(\mathrm{NMe}_{2}\right)_{2}(4.1 \mathrm{mg}, 0.020 \mathrm{mmol}, 0.2$ equiv), 3-hexyne ( $24.6 \mathrm{mg}, 0.3 \mathrm{mmol}, 3$ equiv), azobenzene ( $18.2 \mathrm{mg}, 0.1 \mathrm{mmol}$, 1 equiv), 1,3,5-trimethoxybenzene ( $5.0 \mathrm{mg}, 0.03 \mathrm{mmol}, 0.3$ equiv, internal standard) and $0.5 \mathrm{~mL}$ of $\mathrm{C}_{6} \mathrm{D}_{5} \mathrm{Br}$ were added to a J-Young NMR tube. The reaction mixture was then sealed and heated in a preheated oil bath at $145^{\circ} \mathrm{C}$ for $22 \mathrm{~h} .{ }^{1} \mathrm{H}$ NMR spectra were collected before and after heating to monitor the reaction.
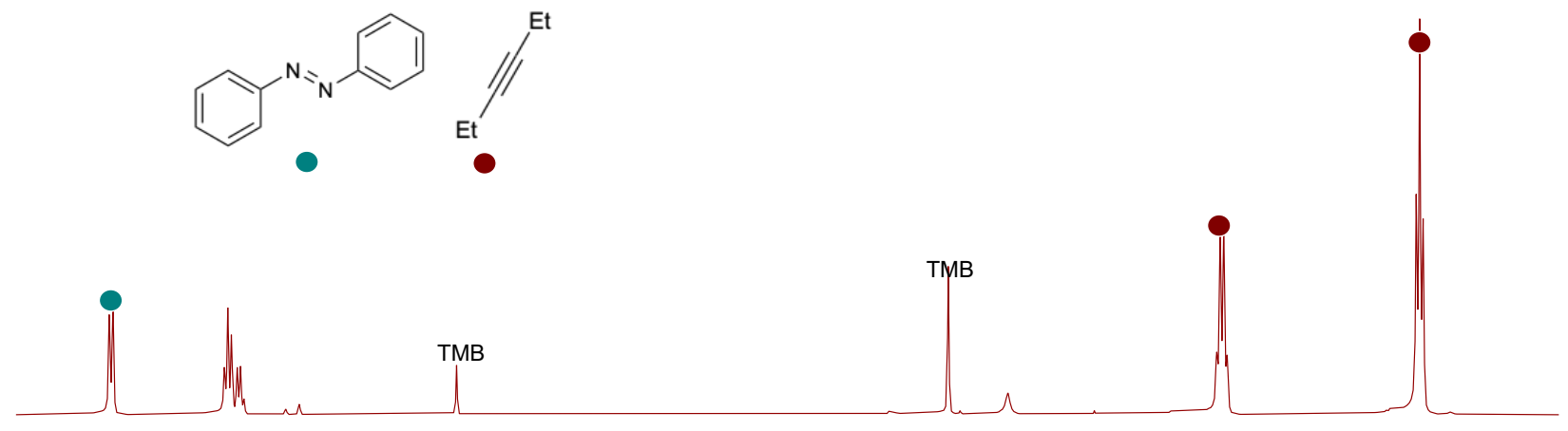<smiles>CCC(=[PH2])CC</smiles><smiles>CCc1[nH]c(CC)c(CC)c1CC</smiles>
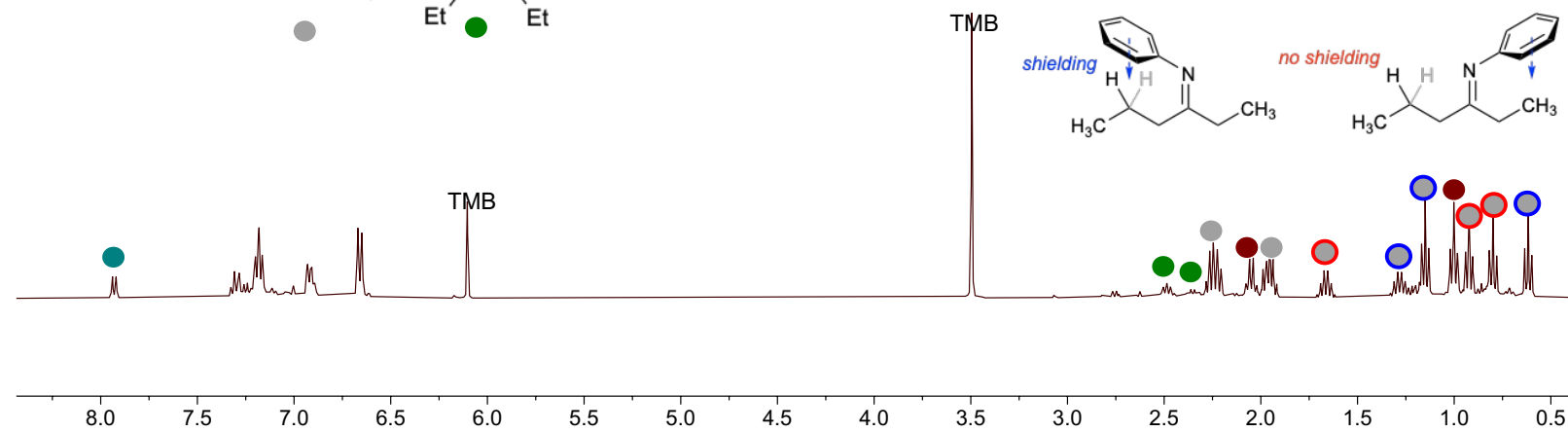

5.0

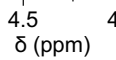

Figure S3. Stacked ${ }^{1} \mathrm{H}$ NMR spectra of $\mathrm{TiCl}_{2}\left(\mathrm{NMe}_{2}\right)_{2}$-catalyzed hydroamination of 3-hexyne with azobenzene in $\mathrm{C}_{6} \mathrm{D}_{5} \mathrm{Br}$. Top: $\mathrm{t}=0$. Bottom: $\mathrm{t}=22 \mathrm{~h} .3$ is a mixture of $\mathrm{E} / \mathrm{Z}$ isomers (grey with blue outline $=\mathrm{Z}$ isomer; grey with red outline $=\mathrm{E}$ isomer). Refer to Figure $\mathrm{S} 15$ for ${ }^{1} \mathrm{H}-{ }^{1} \mathrm{H}$ COSY NMR of 3. 


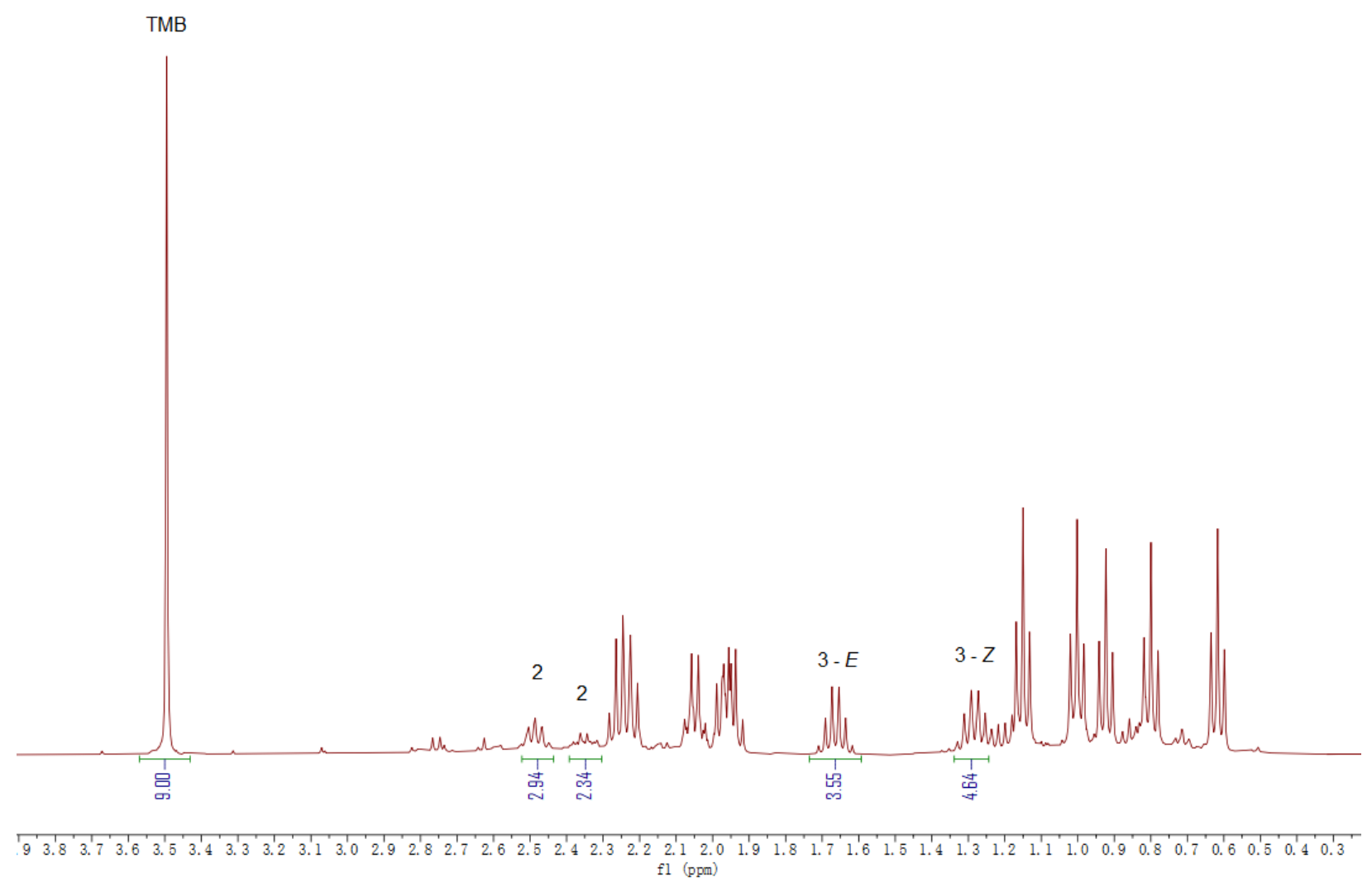

Figure S4. $\mathrm{t}=22 \mathrm{~h}{ }^{1} \mathrm{H}$ NMR spectrum of $\mathrm{TiCl}_{2}\left(\mathrm{NMe}_{2}\right)_{2}$-catalyzed hydroamination of 3-hexyne with azobenzene in $\mathrm{C}_{6} \mathrm{D}_{5} \mathrm{Br}$ for yield calculation. 3 is a mixture of $\mathrm{E} / \mathrm{Z}$ isomers.

Example yield calculation:

TMB: $\frac{5 \mathrm{mg}}{168.19 \mathrm{mg} / \mathrm{mmol}}=0.0297 \mathrm{mmol} \mathrm{TMB} \approx 0.03 \mathrm{mmol} \mathrm{TMB}$

Imine (3):

At $\delta=1.66 \mathrm{ppm}$ (E isomer): $\quad \frac{3.55 \text { integration }}{2 \mathrm{H}}=1.78 \frac{\mathrm{int}}{\mathrm{H}}$

$$
\begin{aligned}
& 1.78 \frac{\text { int }}{H} * 0.03 \text { mmol TMB }=0.0533 \text { mmol imine for } E \text { isomer } \\
& \text { At } \delta=1.28 \mathrm{ppm}(\mathrm{Z} \text { isomer }): \quad \frac{4.64 \text { integration }}{2 \mathrm{H}}=2.32 \frac{\mathrm{int}}{\mathrm{H}} \\
& 2.32 \frac{\text { int }}{H} * 0.03 \text { mmol TMB }=0.0696 \text { mmol imine for } Z \text { isomer } \\
& \sum(E \text { and } Z \text { isomers })=0.1229 \text { mmol imine } \\
& \frac{0.1229 \mathrm{mmol} \text { imine }}{0.2 \mathrm{mmol} \text { nitrene }}=62 \% \text { yield of both isomers }
\end{aligned}
$$


Isotope Labeling Study with 3-Hexyne- $d_{10}$ (eqn 3)

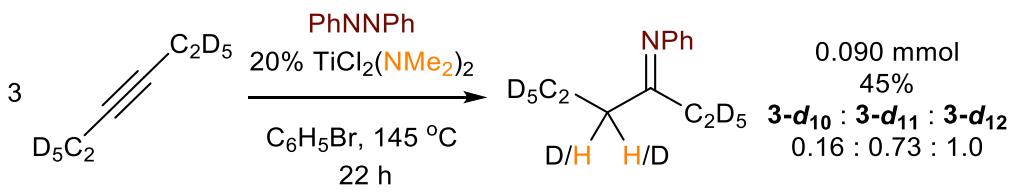

$\mathrm{TiCl}_{2}\left(\mathrm{NMe}_{2}\right)_{2}\left(4.1 \mathrm{mg}, 0.020 \mathrm{mmol}, 0.2\right.$ equiv), 3-hexyne- $d_{10}(27.7 \mathrm{mg}, 0.3 \mathrm{mmol}, 3$ equiv), azobenzene ( $18.2 \mathrm{mg}, 0.1$ mmol, 1 equiv), 1,3,5-trimethoxybenzene ( $5.0 \mathrm{mg}, 0.03 \mathrm{mmol}, 0.3$ equiv, ${ }^{1} \mathrm{H}$ NMR internal standard), $\mathrm{C}_{6} \mathrm{D}_{6}(2.5 \mu \mathrm{L}$, $0.028 \mathrm{mmol}, 0.28$ equiv, ${ }^{2} \mathrm{H}$ NMR internal standard) and $0.5 \mathrm{~mL}$ of $\mathrm{C}_{6} \mathrm{H}_{5} \mathrm{Br}$ were added to a J-Young NMR tube. The reaction mixture was then sealed and heated in a preheated oil bath at $145{ }^{\circ} \mathrm{C}$ for $22 \mathrm{~h} .{ }^{1} \mathrm{H}$ and ${ }^{2} \mathrm{H}$ NMR spectra were collected before and after heating to monitor the reaction. The reaction mixture was then poured into $5 \mathrm{~mL}$ of benchtop DCM, filtered. The resulting mixture containing three isotopic product isomers was characterized by ESI-MS.

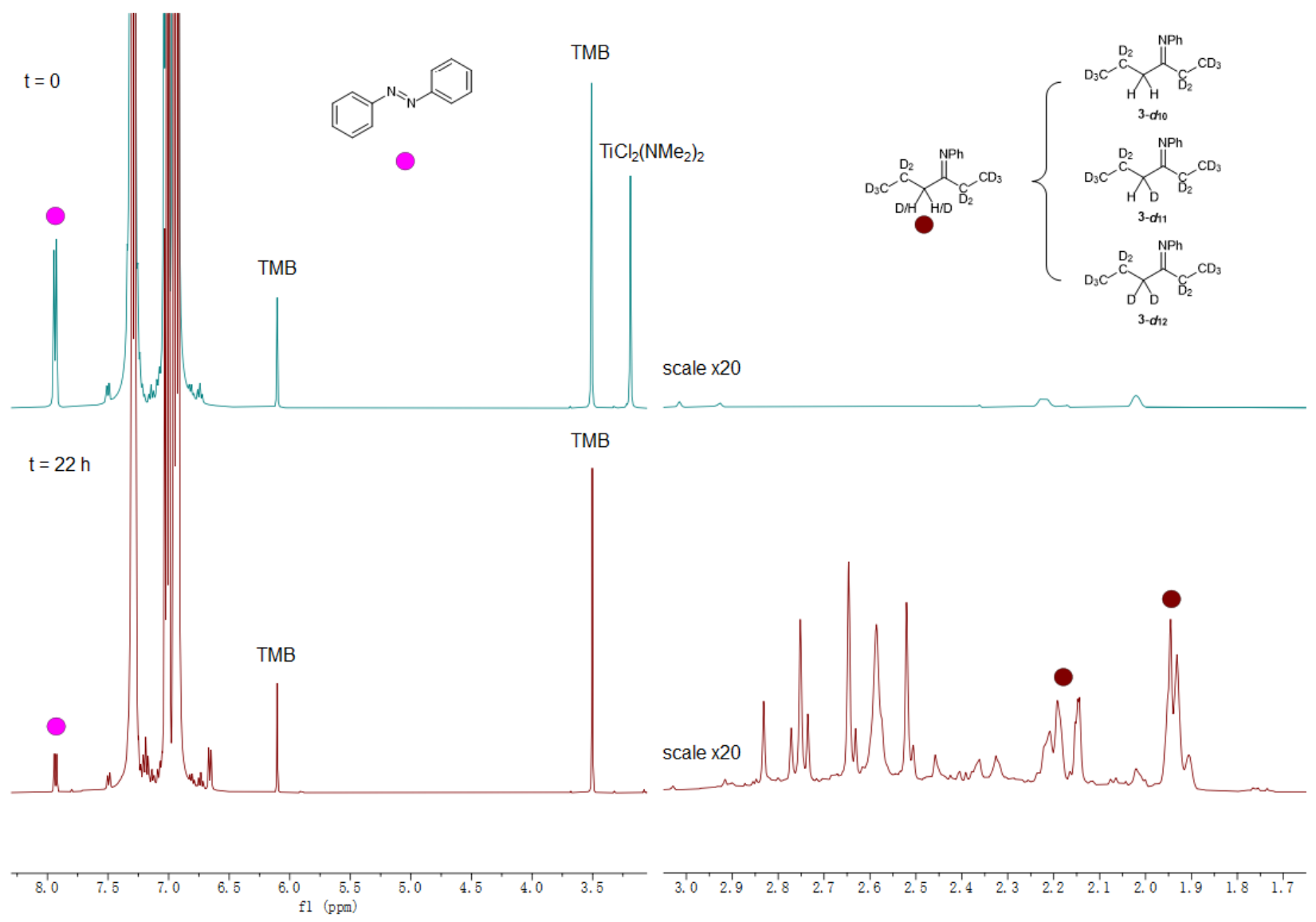

Figure S5. Stacked ${ }^{1} \mathrm{H}$ NMR spectra of $\mathrm{TiCl}_{2}\left(\mathrm{NMe}_{2}\right)_{2}$-catalyzed hydroamination of 3-hexyne- $d_{10}$ with azobenzene in $\mathrm{C}_{6} \mathrm{H}_{5} \mathrm{Br}$. Top: $\mathrm{t}=0$. Bottom: $\mathrm{t}=\mathbf{2 2} \mathrm{h} \cdot \mathbf{3}-\boldsymbol{d}_{\mathbf{1 0}}, \mathbf{3}-\boldsymbol{d}_{11}$ and $\mathbf{3}-\boldsymbol{d}_{\mathbf{1 2}}$ are mixture of $\mathrm{E} / \mathrm{Z}$ isomers. 

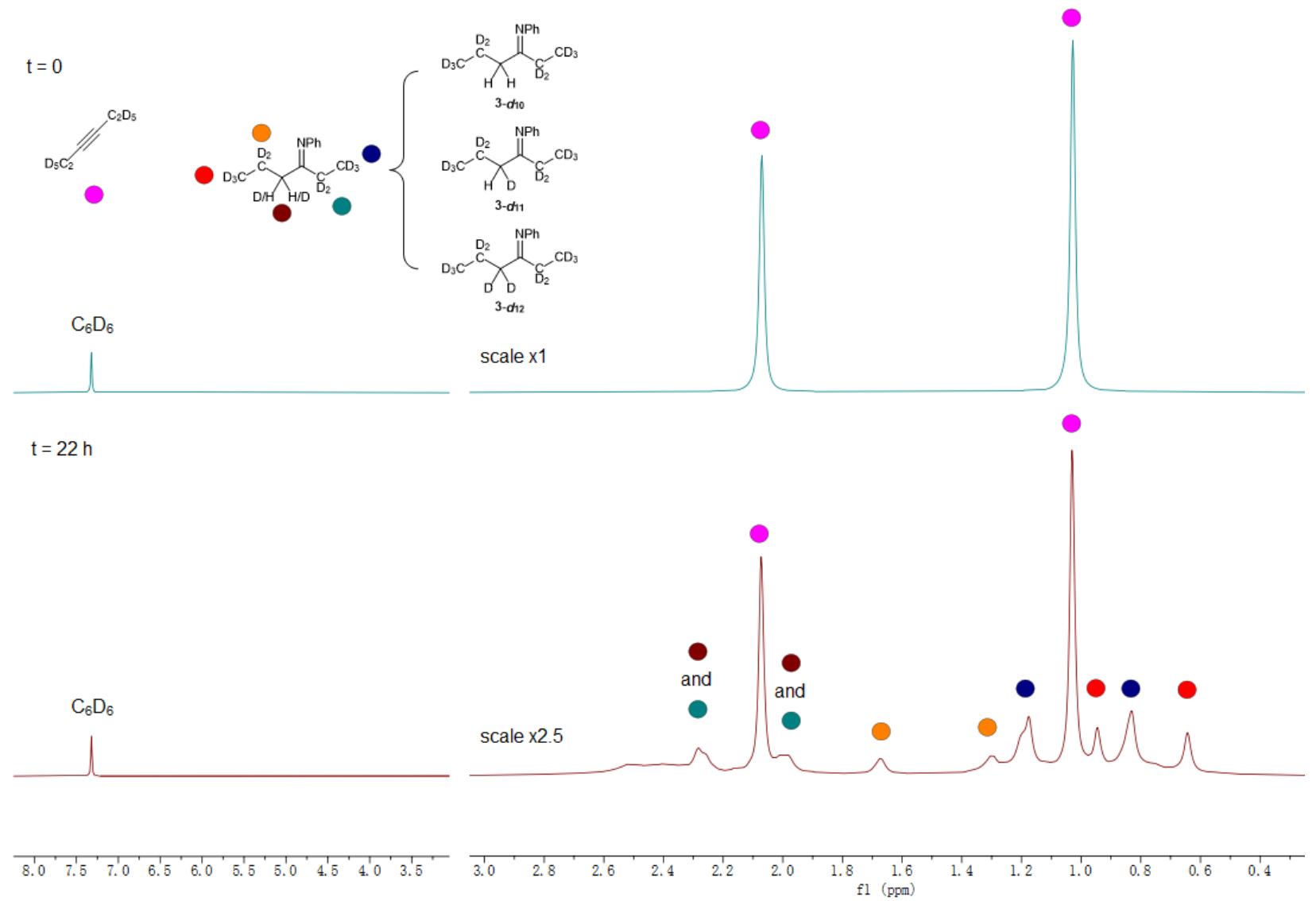

Figure S6. Stacked ${ }^{2} \mathrm{H}$ NMR spectra of $\mathrm{TiCl}_{2}\left(\mathrm{NMe}_{2}\right)_{2}$-catalyzed hydroamination of 3-hexyne- $d_{10}$ with azobenzene in $\mathrm{C}_{6} \mathrm{H}_{5} \mathrm{Br}$. Top: $\mathrm{t}=0$. Bottom: $\mathrm{t}=\mathbf{2 2} \mathrm{h}$. 3- $\boldsymbol{d}_{\mathbf{1 0}}, \mathbf{3}-\boldsymbol{d}_{\mathbf{1 1}}$ and $\mathbf{3}-\boldsymbol{d}_{\mathbf{1 2}}$ are mixture of $\mathrm{E} / \mathrm{Z}$ isomers. 


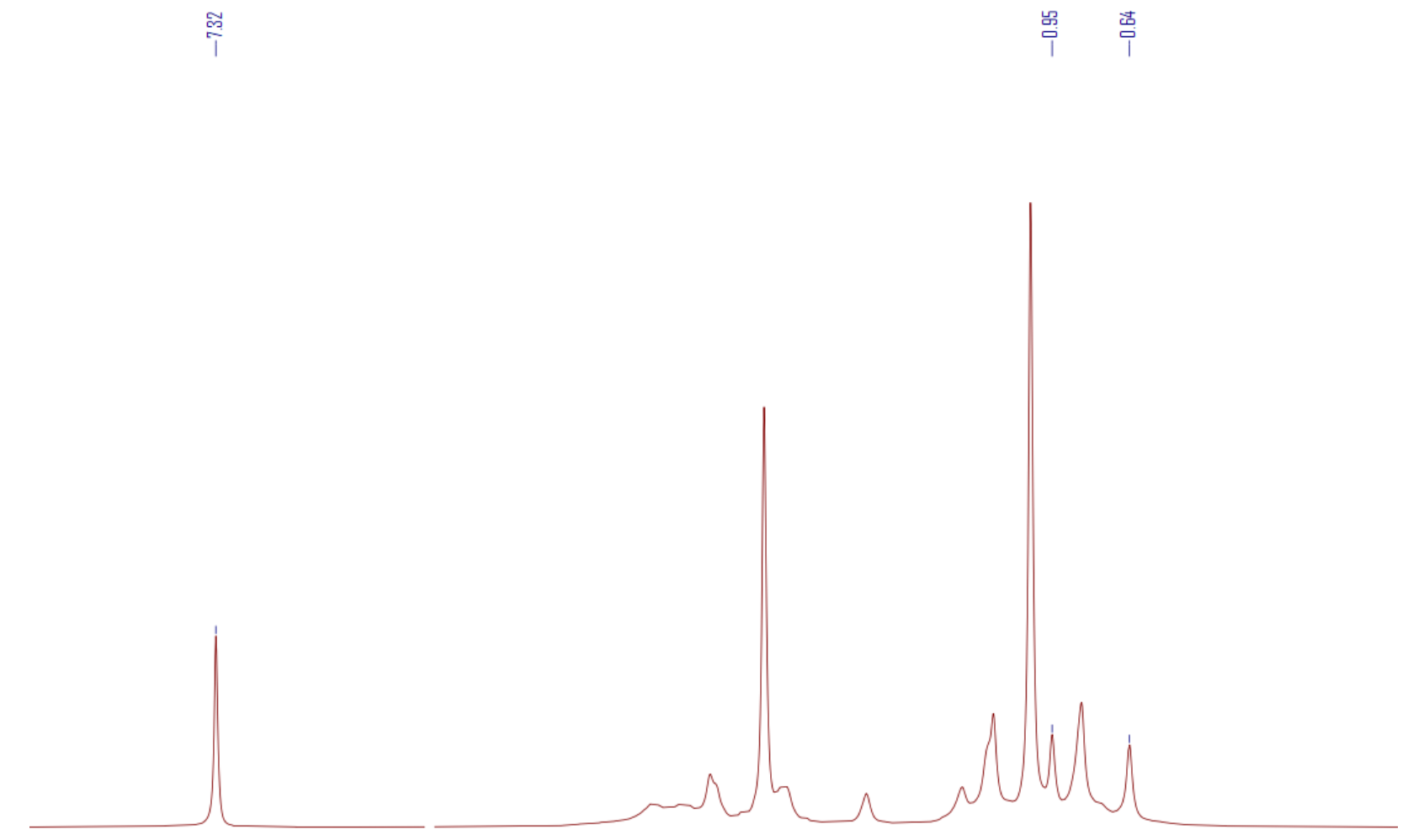

\begin{tabular}{|c|c|c|c|c|c|c|c|c|c|c|c|}
\hline \multirow[t]{2}{*}{8.0} & & \multirow[t]{2}{*}{\begin{tabular}{l|l|}
7.6 & 7.4 \\
\end{tabular}} & \multirow[t]{2}{*}{7.2} & 7.0 & $6.8 \quad 6.6$ & \multirow[t]{2}{*}{ 3. 2} & \begin{tabular}{|l|l|l|}
3.0 & 2.8 & 2.6 \\
\end{tabular} & $\begin{array}{rrr}2.4 & 2.2 & 2.0 \\
2 \mathrm{H} & (\mathrm{ppm}) & \end{array}$ & $\begin{array}{lllll}1.8 & 1.6 & 1.4 & 1.2\end{array}$ & \begin{tabular}{c|cccc}
$1^{\prime} 0$ & 0.8 & 0.6 & 0.4 & 0.2 \\
& & & &
\end{tabular} & $0.0^{\prime}-0^{\prime} 2^{\prime}-0$. \\
\hline & & & & & $\delta(\mathrm{ppm})$ & & Assignment & $\#$ of $\mathrm{H}$ & Peak Area & Amount (mmol) & Yield (\%) \\
\hline & & \multicolumn{2}{|l|}{$\mathrm{C}_{6} \mathrm{D}_{6}$} & & 7.32 & & Ar-D & 6 & 5590.7 & 0.028 & n.a. \\
\hline \multicolumn{4}{|c|}{$3-d_{10}, 3-d_{11}, 3-d_{12}$} & & $0.95,0.64$ & & Imine $\gamma-\mathrm{CD}_{3}$ & 3 & 8999.7 & 0.090 & 45 \\
\hline
\end{tabular}

Figure S7. $\mathrm{t}=22 \mathrm{~h}{ }^{2} \mathrm{H}$ NMR spectrum of $\mathrm{TiCl}_{2}\left(\mathrm{NMe}_{2}\right)_{2}$-catalyzed hydroamination of 3-hexyne- $d_{10}$ with azobenzene in $\mathrm{C}_{6} \mathrm{H}_{5} \mathrm{Br}$ for yield calculation. The peak area of selected ${ }^{2} \mathrm{H}$ NMR peaks were calculated by Gaussian-Lorentzian fitting to omit the influence from baseline overlapping. ${ }^{5}$ 


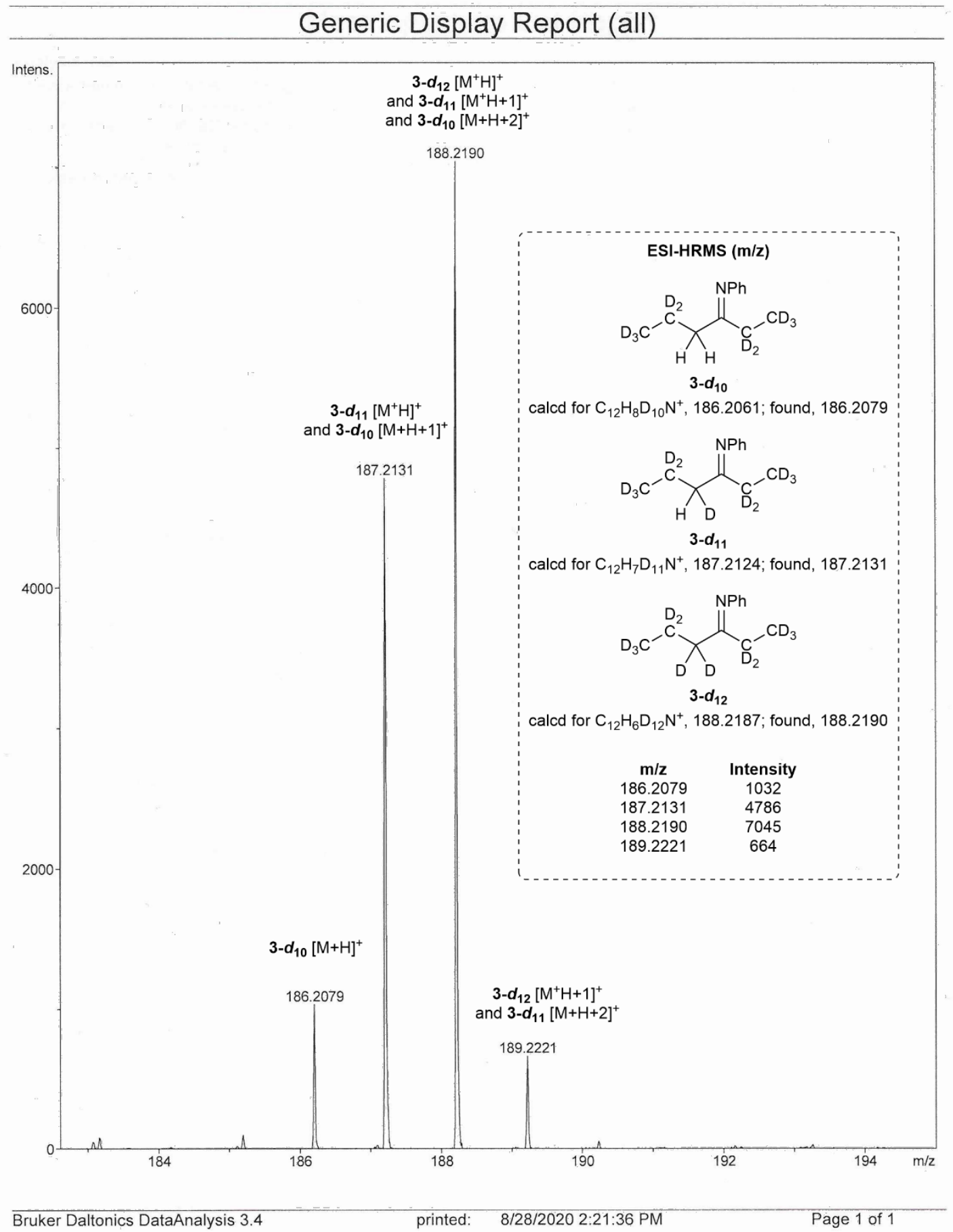

Figure S8. HR-ESI mass spectrum of the product mixture of $\mathrm{TiCl}_{2}\left(\mathrm{NMe}_{2}\right)_{2}$-catalyzed hydroamination of 3-hexyne- $d_{10}$ with azobenzene. 


\section{Product ratio calculation based on ESI-MS:}

Ratio of $[\mathrm{M}+\mathrm{H}]^{+}:[\mathrm{M}+\mathrm{H}+1]^{+}:[\mathrm{M}+\mathrm{H}+2]^{+}$can be calculated based on natural element abundance. ${ }^{6}[\mathrm{M}+\mathrm{H}+3]^{+}$was considered to be negligible in contribution.

Example: $3-\boldsymbol{d}_{\mathbf{1 0}}\left(\mathrm{C}_{12} \mathrm{H}_{7} \mathrm{D}_{10} \mathrm{~N}\right)$

$$
\begin{gathered}
{[\mathrm{M}+\mathrm{H}]^{+} \text {ratio }=\text { ratio of } \mathrm{C}_{12} \mathrm{H}_{7} \mathrm{D}_{10} \mathrm{~N}=1} \\
{[\mathrm{M}+\mathrm{H}+1]^{+} \text {ratio = ratio of } \mathrm{C}_{11}{ }^{13} \mathrm{CH}_{7} \mathrm{D}_{10} \mathrm{~N}+\text { ratio of } \mathrm{C}_{12} \mathrm{H}_{7} \mathrm{D}_{10}{ }^{15} \mathrm{~N}=0.133+0.004=0.137} \\
{[\mathrm{M}+\mathrm{H}+2]^{+} \text {ratio = ratio of } \mathrm{C}_{10}{ }^{13} \mathrm{C}_{2} \mathrm{H}_{7} \mathrm{D}_{10} \mathrm{~N} \text { and ratio of } \mathrm{C}_{11}{ }^{13} \mathrm{CH}_{7} \mathrm{D}_{10}{ }^{15} \mathrm{~N}=0.016+0.001=0.017}
\end{gathered}
$$

\begin{tabular}{|c|c|c|c|c|}
\hline Compound & Formula & {$[\mathrm{M}+\mathrm{H}]^{+}$} & {$[\mathrm{M}+\mathrm{H}+1]^{+}$} & {$[\mathrm{M}+\mathrm{H}+2]^{+}$} \\
\hline $3-d_{10}$ & $\mathrm{C}_{12} \mathrm{H}_{7} \mathrm{D}_{10} \mathrm{~N}$ & 1.00 & 0.137 & 0.017 \\
\hline $3-d_{11}$ & $\mathrm{C}_{12} \mathrm{H}_{6} \mathrm{D}_{11} \mathrm{~N}$ & 1.00 & 0.137 & 0.017 \\
\hline $3-d_{12}$ & $\mathrm{C}_{12} \mathrm{H}_{5} \mathrm{D}_{12} \mathrm{~N}$ & 1.00 & 0.137 & 0.017 \\
\hline
\end{tabular}

List of isotopic peak ratio of the compounds:

\begin{tabular}{|c|c|c|c|}
\hline $\mathrm{m} / \mathrm{z}$ & Assignment & Amount & Intensity \\
\hline 186.2079 & 3- $\boldsymbol{d}_{10}[\mathrm{M}+\mathrm{H}]^{+}$ & {$\left[3-d_{10}\right]$} & 1032 \\
\hline 187.2131 & $\begin{array}{c}3-d_{11}[\mathrm{M}+\mathrm{H}]^{+} \\
\text {and } 3-d_{10}[\mathrm{M}+\mathrm{H}+1]^{+}\end{array}$ & {$\left[3-d_{11}\right]+0.137\left[\mathbf{3}-d_{10}\right]$} & 4786 \\
\hline 188.2190 & $\begin{array}{l}\text { 3- } d_{12}[\mathrm{M}+\mathrm{H}]^{+} \\
\text {and } 3-d_{11}[\mathrm{M}+\mathrm{H}+1]^{+} \\
\text {and } 3-d_{10}[\mathrm{M}+\mathrm{H}+2]^{+}\end{array}$ & {$\left[3-d_{12}\right]+0.137\left[3-d_{11}\right]+0.017\left[3-d_{10}\right]$} & 7045 \\
\hline
\end{tabular}

Mass list

The ratio can thus be calculated as $\left[3-\boldsymbol{d}_{10}\right]:\left[\mathbf{3}-\boldsymbol{d}_{11}\right]:\left[\mathbf{3}-\boldsymbol{d}_{12}\right]=0.16: 0.73: 1.0$ 
Isotope Labeling Study with 3-Hexyne- $d_{10}$ and $10 \%$ Catalyst Loading

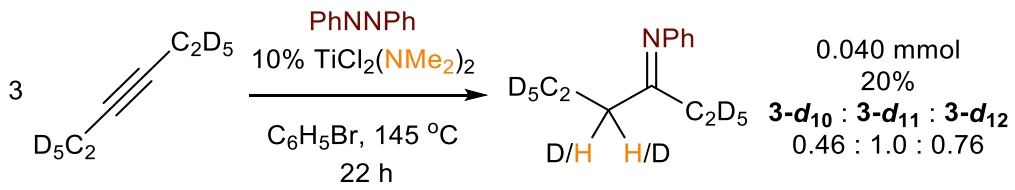

$\mathrm{TiCl}_{2}\left(\mathrm{NMe}_{2}\right)_{2}\left(2.1 \mathrm{mg}, 0.010 \mathrm{mmol}, 0.1\right.$ equiv), 3-hexyne- $d_{10}(27.7 \mathrm{mg}, 0.3 \mathrm{mmol}, 3$ equiv), azobenzene ( $18.2 \mathrm{mg}, 0.1$ mmol, 1 equiv), 1,3,5-trimethoxybenzene $\left(5.0 \mathrm{mg}, 0.03 \mathrm{mmol}, 0.3\right.$ equiv, ${ }^{1} \mathrm{H}$ NMR internal standard), $\mathrm{C}_{6} \mathrm{D}_{6}(2.5 \mu \mathrm{L}$, $0.028 \mathrm{mmol}, 0.28$ equiv, ${ }^{2} \mathrm{H}$ NMR internal standard) and $0.5 \mathrm{~mL}$ of $\mathrm{C}_{6} \mathrm{H}_{5} \mathrm{Br}$ were added to a J-Young NMR tube. The reaction mixture was then sealed and heated in a preheated oil bath at $145{ }^{\circ} \mathrm{C}$ for $22 \mathrm{~h} .{ }^{1} \mathrm{H}$ and ${ }^{2} \mathrm{H}$ NMR spectra were collected before and after heating to monitor the reaction. The reaction mixture was then poured into $5 \mathrm{~mL}$ of benchtop DCM, filtered. The resulting mixture containing three isotopic product isomers was characterized by ESI-MS.
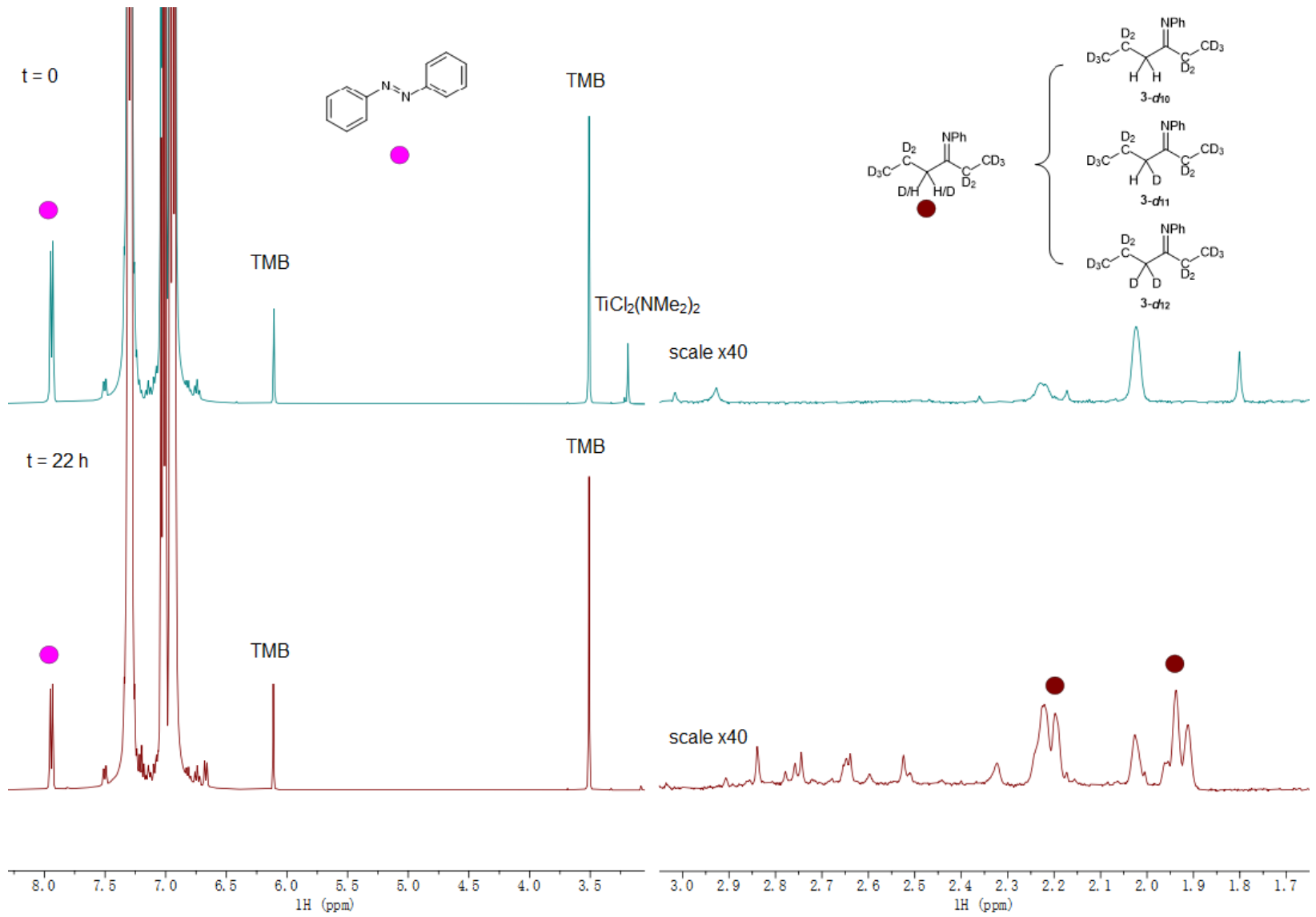

Figure S9. Stacked ${ }^{1} \mathrm{H}$ NMR spectra of $10 \% \mathrm{TiCl}_{2}\left(\mathrm{NMe}_{2}\right)_{2}$-catalyzed hydroamination of 3-hexyne- $d_{10}$ with azobenzene in $\mathrm{C}_{6} \mathrm{H}_{5} \mathrm{Br}$. Top: $\mathrm{t}=\mathbf{0}$. Bottom: $\mathrm{t}=\mathbf{2 2}$ h. $\mathbf{3}-\boldsymbol{d}_{\mathbf{1 0}}, \mathbf{3}-\boldsymbol{d}_{\mathbf{1 1}}$ and $\mathbf{3}-\boldsymbol{d}_{\mathbf{1 2}}$ are mixture of $\mathrm{E} / \mathrm{Z}$ isomers. 

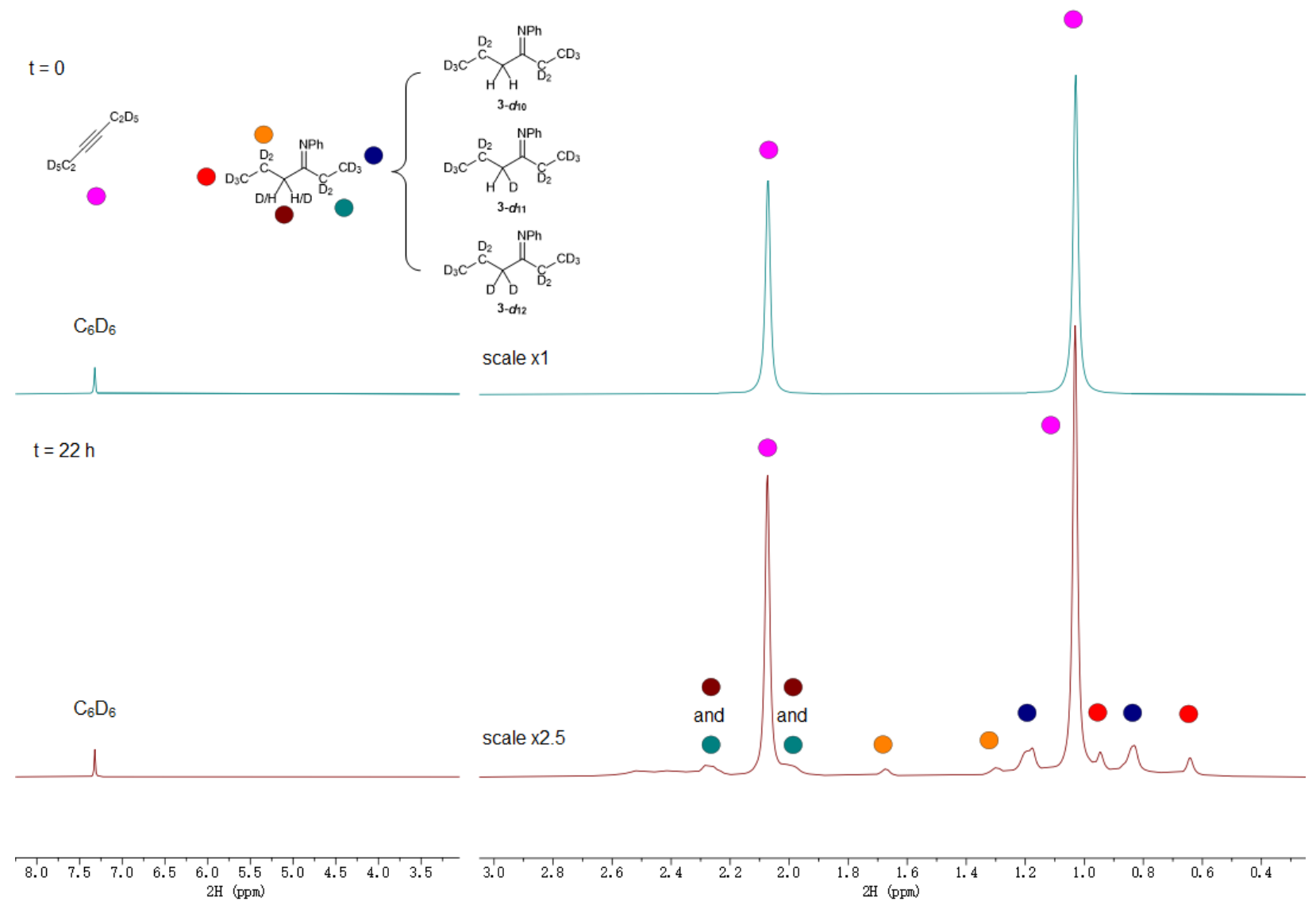

Figure S10. Stacked ${ }^{2} \mathrm{H}$ NMR spectra of $10 \% \mathrm{TiCl}_{2}\left(\mathrm{NMe}_{2}\right)_{2}$-catalyzed hydroamination of 3-hexyne- $d_{10}$ with azobenzene in $\mathrm{C}_{6} \mathrm{H}_{5} \mathrm{Br}$. Top: $\mathrm{t}=\mathbf{0}$. Bottom: $\mathrm{t}=\mathbf{2 2} \mathrm{h} . \mathbf{3}-\boldsymbol{d}_{\mathbf{1 0}}, \mathbf{3}-\boldsymbol{d}_{\mathbf{1 1}}$ and $\mathbf{3}-\boldsymbol{d}_{\mathbf{1 2}}$ are mixture of $\mathrm{E} / \mathrm{Z}$ isomers. 


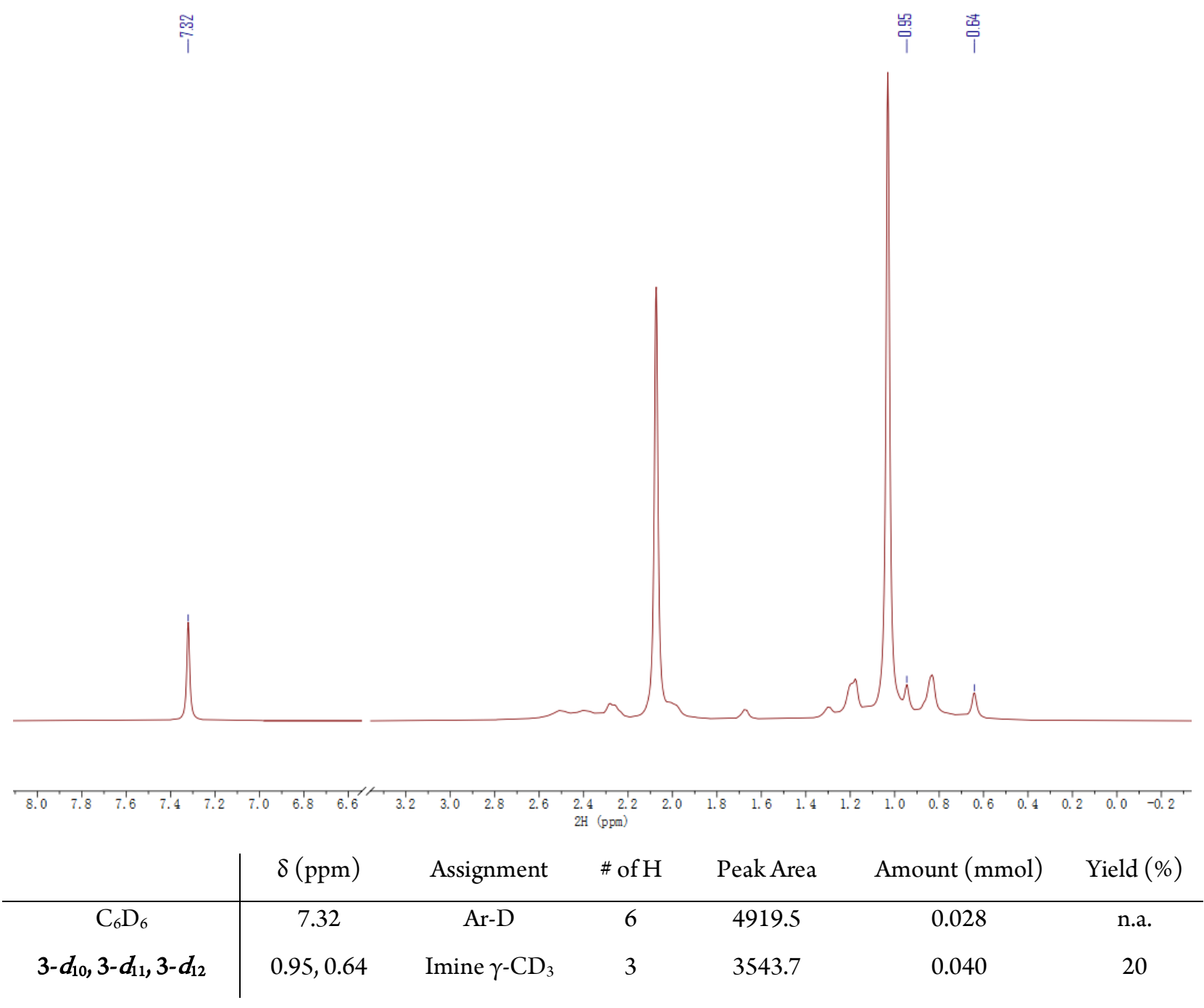

Figure S11. $\mathrm{t}=22 \mathrm{~h}{ }^{2} \mathrm{H}$ NMR spectrum of $10 \% \mathrm{TiCl}_{2}\left(\mathrm{NMe}_{2}\right)_{2}$-catalyzed hydroamination of 3-hexyne- $d_{10}$ with azobenzene in $\mathrm{C}_{6} \mathrm{H}_{5} \mathrm{Br}$ for yield calculation. The peak area of selected ${ }^{2} \mathrm{H}$ NMR peaks were calculated by GaussianLorentzian fitting to omit the influence from baseline overlapping. ${ }^{5}$ 


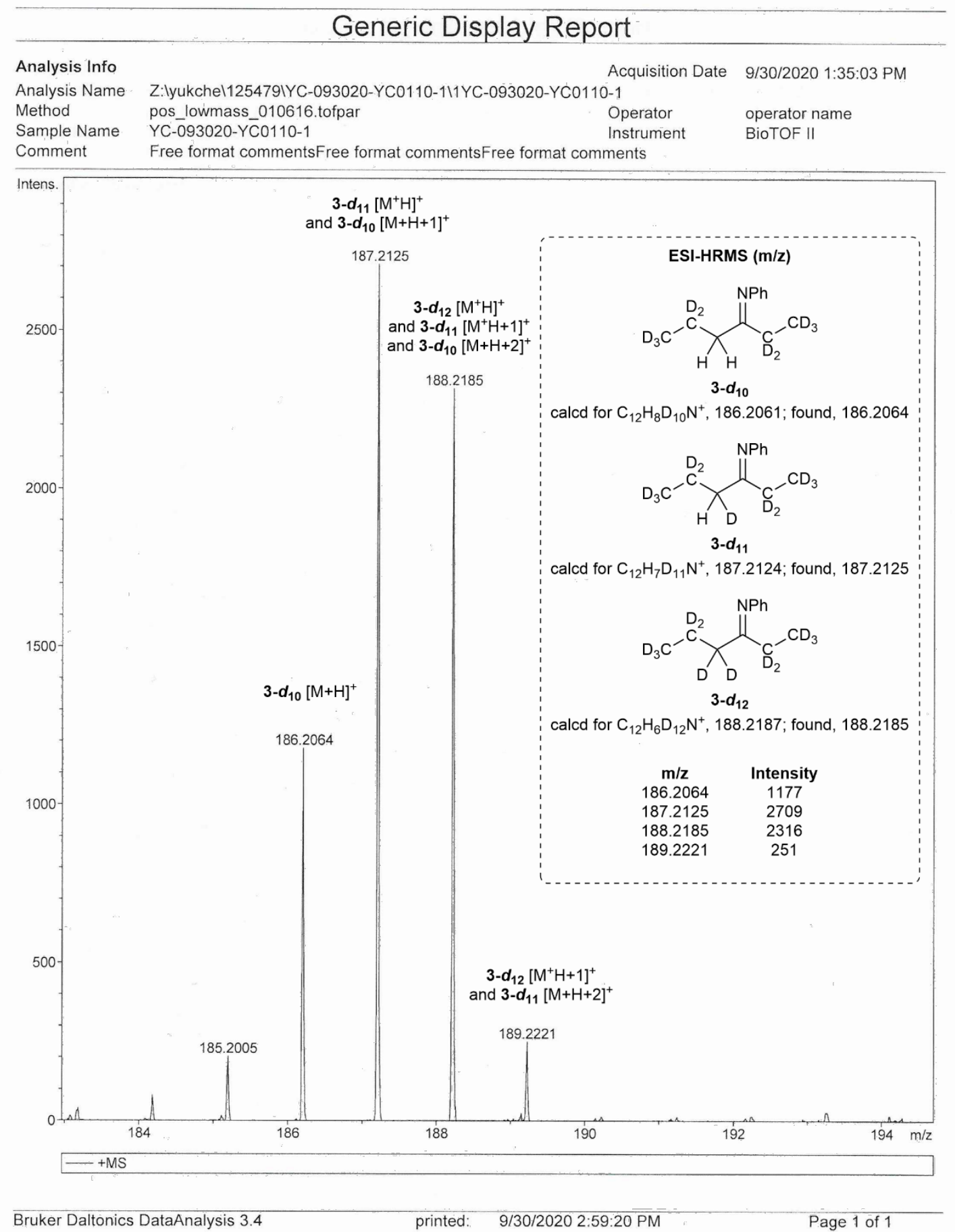

Figure S12. HR-ESI mass spectrum of the product mixture of $10 \% \mathrm{TiCl}_{2}\left(\mathrm{NMe}_{2}\right)_{2}$-catalyzed hydroamination of 3hexyne- $d_{10}$ with azobenzene. 


\section{Product ratio calculation based on ESI-MS:}

The product ratio was determined using the same method as for eqn 3.

Mass list

\begin{tabular}{|c|c|c|c|}
\hline $\mathrm{m} / \mathrm{z}$ & Assignment & Amount & Intensity \\
\hline 186.2064 & 3- $d_{10}[\mathrm{M}+\mathrm{H}]^{+}$ & {$\left[3-d_{10}\right]$} & 1177 \\
\hline 187.2125 & $\begin{array}{l}3-d_{11}[\mathrm{M}+\mathrm{H}]^{+} \\
\text {and } 3-d_{10}[\mathrm{M}+\mathrm{H}+1]^{+}\end{array}$ & {$\left[3-d_{11}\right]+0.137\left[3-d_{10}\right]$} & 2709 \\
\hline 188.2185 & $\begin{array}{l}3-d_{12}[\mathrm{M}+\mathrm{H}]^{+} \\
\text {and } 3-d_{11}[\mathrm{M}+\mathrm{H}+1]^{+} \\
\text {and } 3-d_{10}[\mathrm{M}+\mathrm{H}+2]^{+}\end{array}$ & {$\left[3-d_{12}\right]+0.137\left[3-d_{11}\right]+0.017\left[3-d_{10}\right]$} & 2316 \\
\hline
\end{tabular}

The ratio can thus be calculated as $\left[\mathbf{3}-\boldsymbol{d}_{\mathbf{1 0}}\right]:\left[\mathbf{3}-\boldsymbol{d}_{\mathbf{1 1}}\right]:\left[\mathbf{3}-\boldsymbol{d}_{\mathbf{1 2}}\right]=0.46: 1.0: 0.76$ 


\section{Hydroamination of 3-Hexyne with Azobenzene and 4 (eqn 4)}

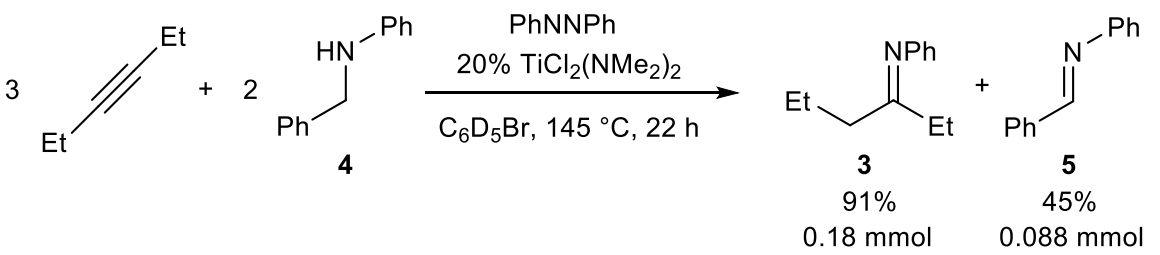

$\mathrm{TiCl}_{2}\left(\mathrm{NMe}_{2}\right)_{2}(4.1 \mathrm{mg}, 0.020 \mathrm{mmol}, 0.2$ equiv), 3-hexyne ( $24.6 \mathrm{mg}, 0.3 \mathrm{mmol}, 3$ equiv), azobenzene $(18.2 \mathrm{mg}, 0.1 \mathrm{mmol}$, 1 equiv), $\mathrm{N}$-benzylaniline ( $36.7 \mathrm{mg}, 0.2 \mathrm{mmol}, 2$ equiv), 1,3,5-trimethoxybenzene ( $5.0 \mathrm{mg}, 0.03 \mathrm{mmol}, 0.3$ equiv, internal standard) and $0.5 \mathrm{~mL}$ of $\mathrm{C}_{6} \mathrm{D}_{5} \mathrm{Br}$ were added to a J-Young NMR tube. The reaction mixture was then sealed and heated in a preheated oil bath at $145^{\circ} \mathrm{C}$ for $22 \mathrm{~h} .{ }^{1} \mathrm{H}$ NMR spectra were collected before and after heating to monitor the reaction.
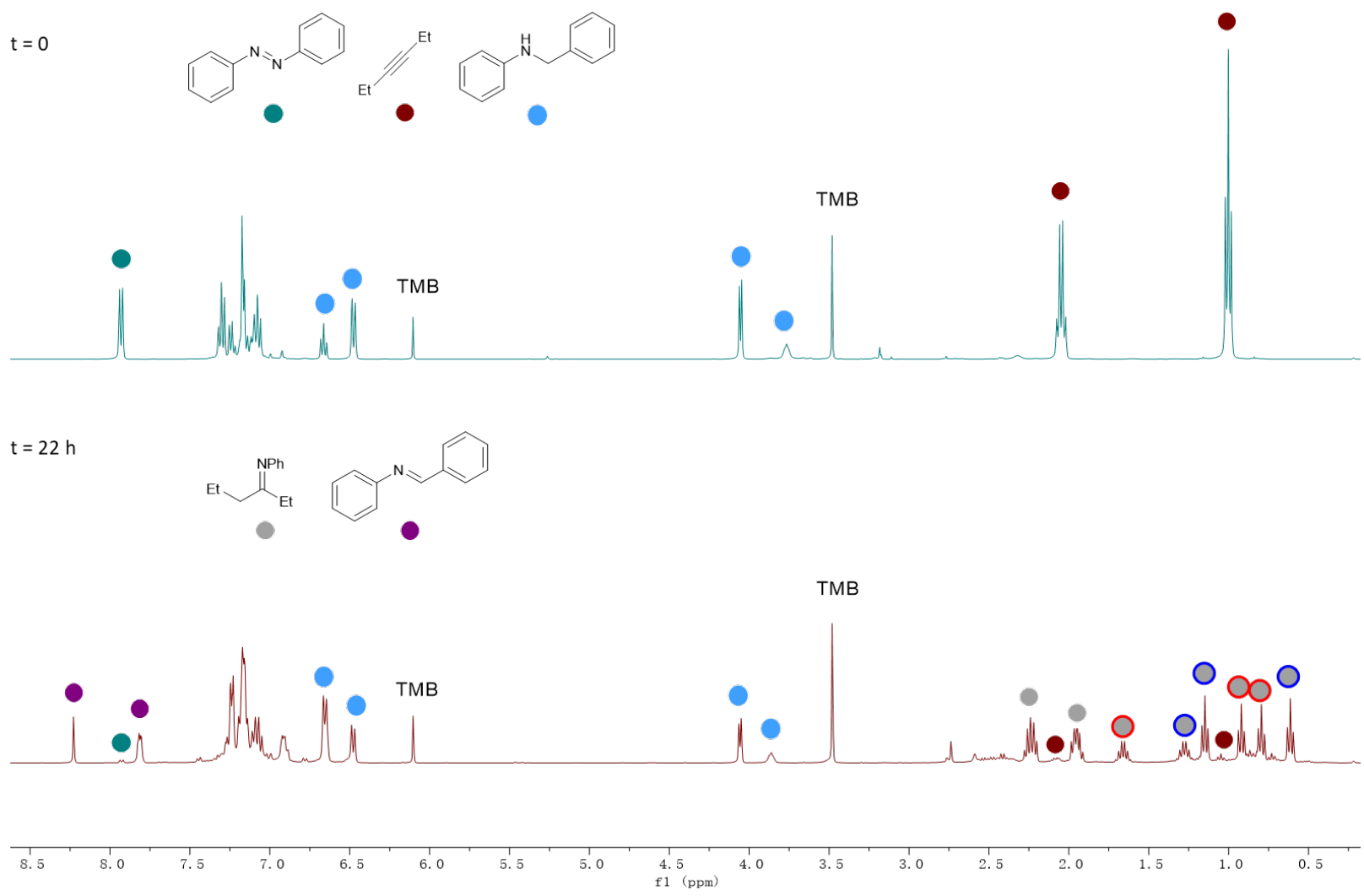

Figure S13. Stacked ${ }^{1} \mathrm{H}$ NMR spectra of $\mathrm{TiCl}_{2}\left(\mathrm{NMe}_{2}\right)_{2}$-catalyzed hydroamination of 3-hexyne with azobenzene and $\mathrm{N}$ benzylaniline (4) in $\mathrm{C}_{6} \mathrm{D}_{5} \mathrm{Br}$. Top: $\mathrm{t}=0$. Bottom: $\mathrm{t}=1 \mathrm{~h} .3$ is a mixture of $\mathrm{E} / \mathrm{Z}$ isomers (grey with blue outline $=\mathrm{Z}$ isomer; grey with red outline $=\mathrm{E}$ isomer). 


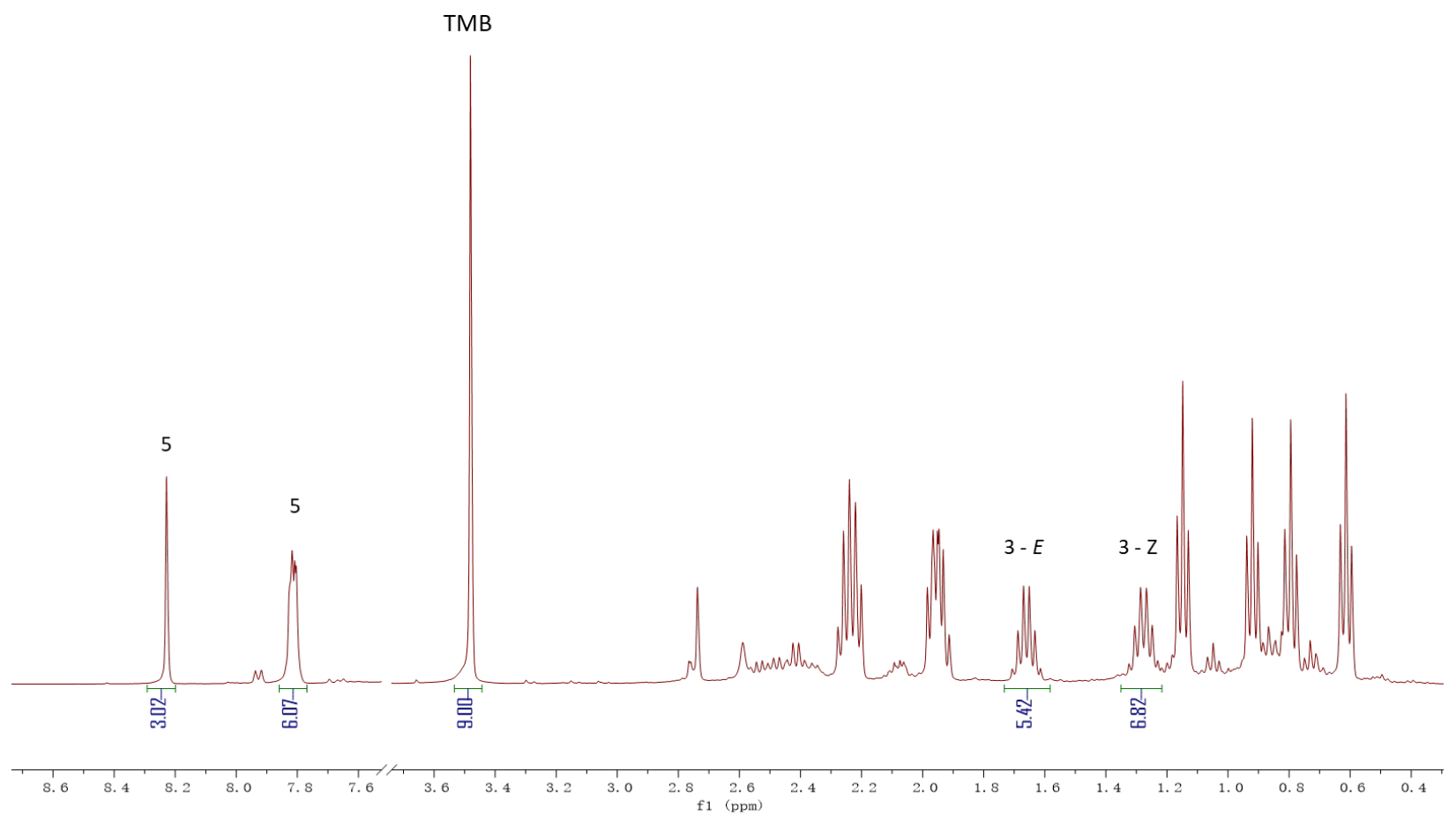

Figure S14. $\mathrm{t}=22 \mathrm{~h}{ }^{1} \mathrm{H}$ NMR spectrum of $\mathrm{TiCl}_{2}\left(\mathrm{NMe}_{2}\right)_{2}$-catalyzed hydroamination of 3-hexyne with azobenzene and $N$-benzylaniline (4) in $\mathrm{C}_{6} \mathrm{D}_{5} \mathrm{Br}$ for yield calculation. 3 is a mixture of $\mathrm{E} / \mathrm{Z}$ isomers.

Example yield calculation:

TMB: $\frac{5 \mathrm{mg}}{168.19 \mathrm{mg} / \mathrm{mmol}}=0.0297 \mathrm{mmol} T M B \approx 0.03 \mathrm{mmol}$ TMB

Imine (3):

At $\delta=1.68 \mathrm{ppm}\left(\mathrm{E}\right.$ isomer): $\quad \frac{5.42 \text { integration }}{2 \mathrm{H}}=2.71 \frac{\mathrm{int}}{\mathrm{H}}$

$$
\begin{aligned}
& 2.71 \frac{\text { int }}{H} * 0.03 \text { mmol TMB }=0.0813 \text { mmol imine for } E \text { isomer } \\
& \text { At } \delta=1.28 \mathrm{ppm}(\mathrm{Z} \text { isomer }): \quad \frac{6.82 \text { integration }}{2 \mathrm{H}}=3.41 \frac{\mathrm{int}}{\mathrm{H}} \\
& 3.41 \frac{\text { int }}{H} * 0.03 \mathrm{mmol} \text { TMB }=0.1023 \mathrm{mmol} \text { imine for } Z \text { isomer } \\
& \sum(E \text { and } Z \text { isomers })=0.1836 \text { mmol imine } \\
& \frac{0.1836 \mathrm{mmol} \text { imine }}{0.2 \mathrm{mmol} \text { nitrene }}=91 \% \text { yield of the sum of both isomers }
\end{aligned}
$$




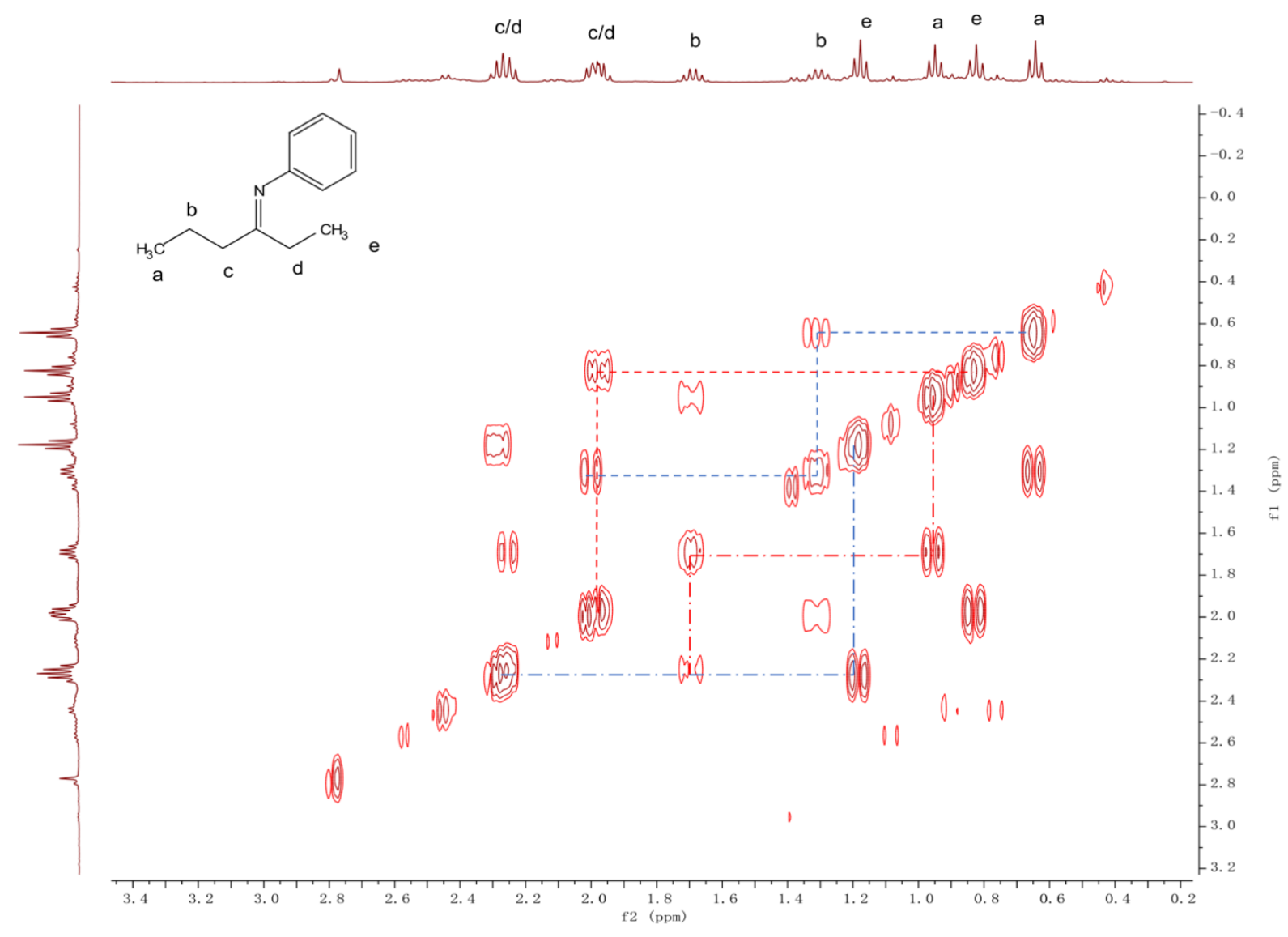

Figure S15. $\mathrm{t}=22 \mathrm{~h}{ }^{1} \mathrm{H}-{ }^{1} \mathrm{H}$ COSY NMR spectra of $\mathrm{TiCl}_{2}\left(\mathrm{NMe}_{2}\right)_{2}$-catalyzed hydroamination of 3-hexyne with azobenzene and $\mathrm{N}$-benzylaniline $(4)$ in $\mathrm{C}_{6} \mathrm{D}_{5} \mathrm{Br}$ for isomer proton assignments of $\mathrm{N}$-phenylhexan-3-imine. 
Transfer Hydrogenation of 4 to Azobenzene (eqn 5)

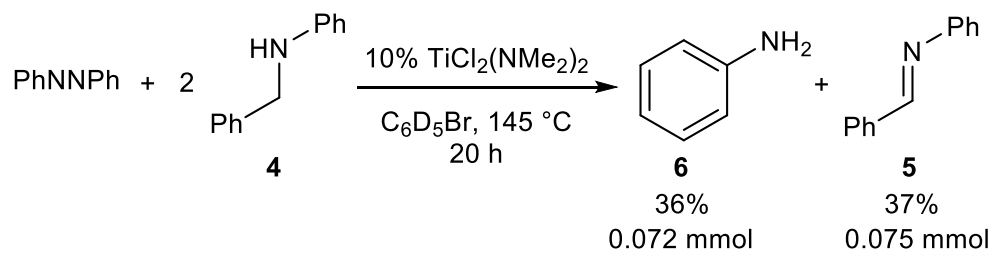

$\mathrm{TiCl}_{2}\left(\mathrm{NMe}_{2}\right)_{2}(2.2 \mathrm{mg}, 0.011 \mathrm{mmol}, 0.1$ equiv), azobenzene ( $18.7 \mathrm{mg}, 0.103 \mathrm{mmol}, 1$ equiv), N-benzylaniline ( $37.0 \mathrm{mg}$, $0.202 \mathrm{mmol}, 1.96$ equiv), 1,3,5-trimethoxybenzene $(2.3 \mathrm{mg}, 0.014 \mathrm{mmol}, 0.13$ equiv, internal standard $)$ and $0.5 \mathrm{~mL}$ of $\mathrm{C}_{6} \mathrm{D}_{5} \mathrm{Br}$ were added to an NMR tube. The reaction mixture was then sealed and heated in a preheated oil bath at $145^{\circ} \mathrm{C}$ for $20 \mathrm{~h} .{ }^{1} \mathrm{H}$ NMR spectra were collected before and after heating to monitor the reaction.

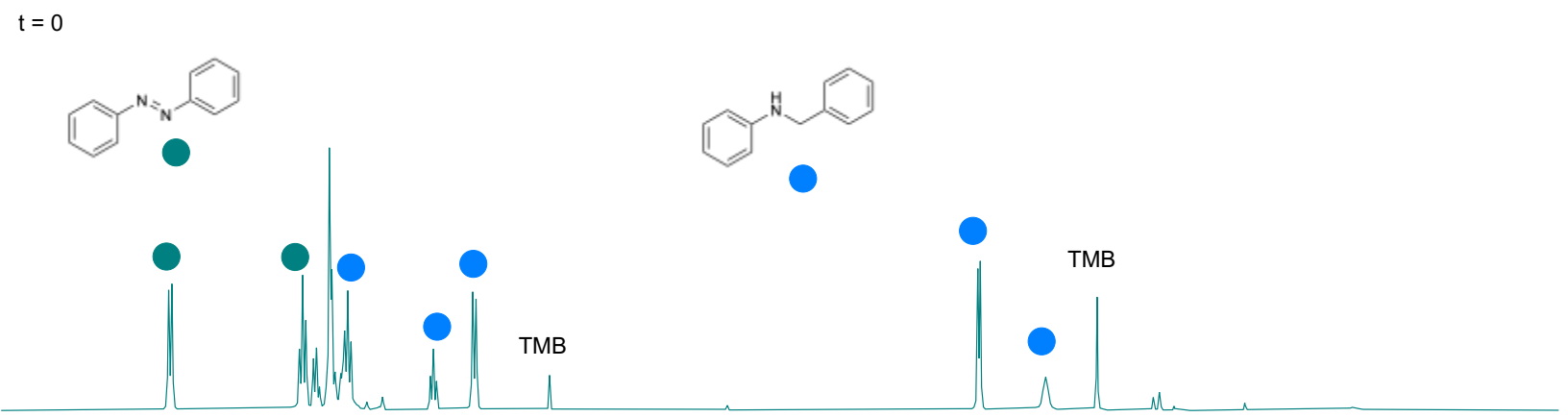

$t=20 h$

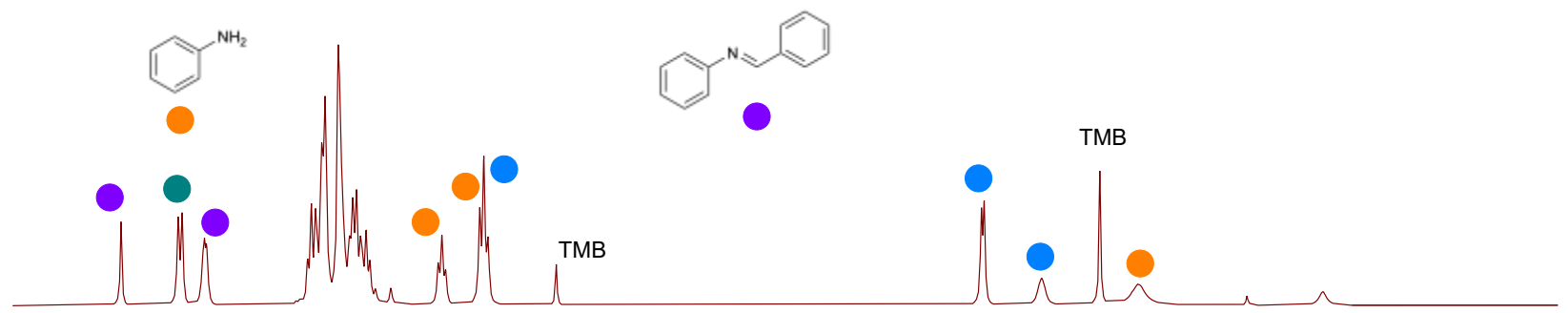

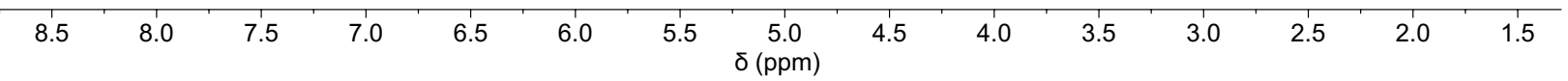

Figure S16. Stacked ${ }^{1} \mathrm{H}$ NMR spectra of $\mathrm{TiCl}_{2}\left(\mathrm{NMe}_{2}\right)_{2}$-catalyzed transfer hydrogenation of 4 to azobenzene in $\mathrm{C}_{6} \mathrm{D}_{5} \mathrm{Br}$. Top: $\mathrm{t}=0$. Bottom: $\mathrm{t}=20 \mathrm{~h}$. 


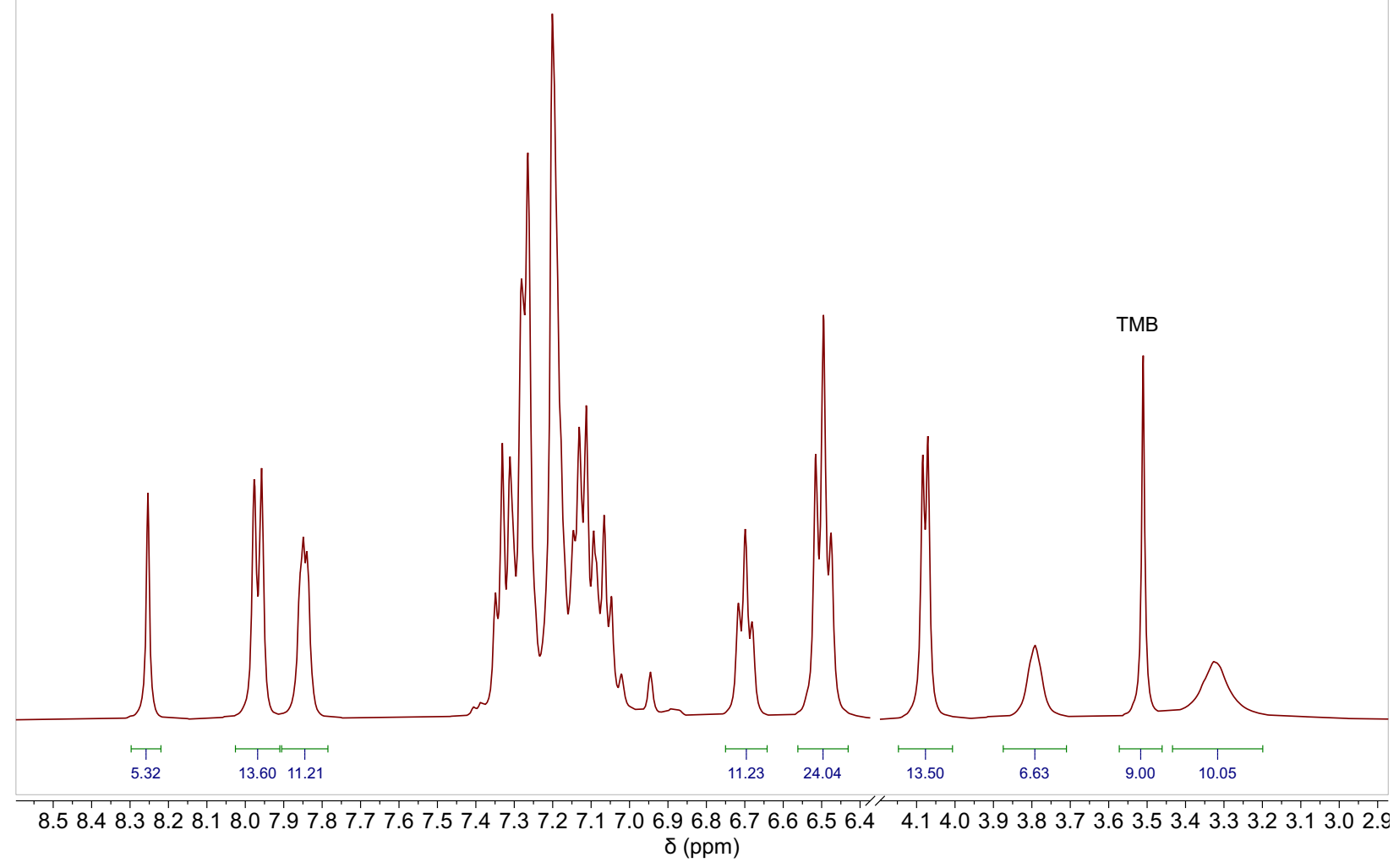

Figure S17. ${ }^{1} \mathrm{H}$ NMR spectrum of $\mathrm{TiCl}_{2}\left(\mathrm{NMe}_{2}\right)_{2}$-catalyzed transfer hydrogenation of 4 to azobenzene in $\mathrm{C}_{6} \mathrm{D}_{5} \mathrm{Br}_{\text {for yield }}$ calculation. 


\section{Transfer Hydrogenation of $\mathrm{TiCl}_{2}\left(\mathrm{NMe}_{2}\right)_{2}$ to Azobenzene}

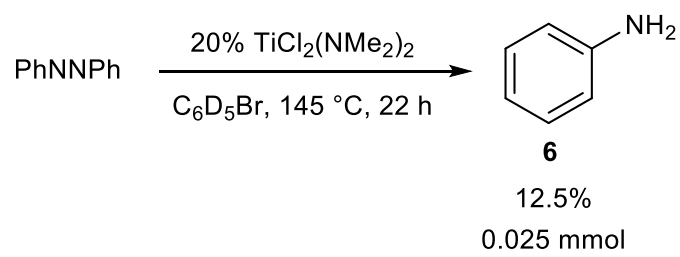

$\mathrm{TiCl}_{2}\left(\mathrm{NMe}_{2}\right)_{2}$ ( $4.1 \mathrm{mg}, 0.020 \mathrm{mmol}, 0.2$ equiv), azobenzene ( $18.2 \mathrm{mg}, 0.1 \mathrm{mmol}, 1$ equiv), 1,3,5-trimethoxybenzene (5.0 mg, $0.03 \mathrm{mmol}, 0.3$ equiv, internal standard) and $0.5 \mathrm{~mL}$ of $\mathrm{C}_{6} \mathrm{D}_{5} \mathrm{Br}$ were added to a J-Young NMR tube. The reaction mixture was then sealed and heated in a preheated oil bath at $145{ }^{\circ} \mathrm{C}$ for $22 \mathrm{~h} .{ }^{1} \mathrm{H}$ NMR spectra were collected before and after heating to monitor the reaction.
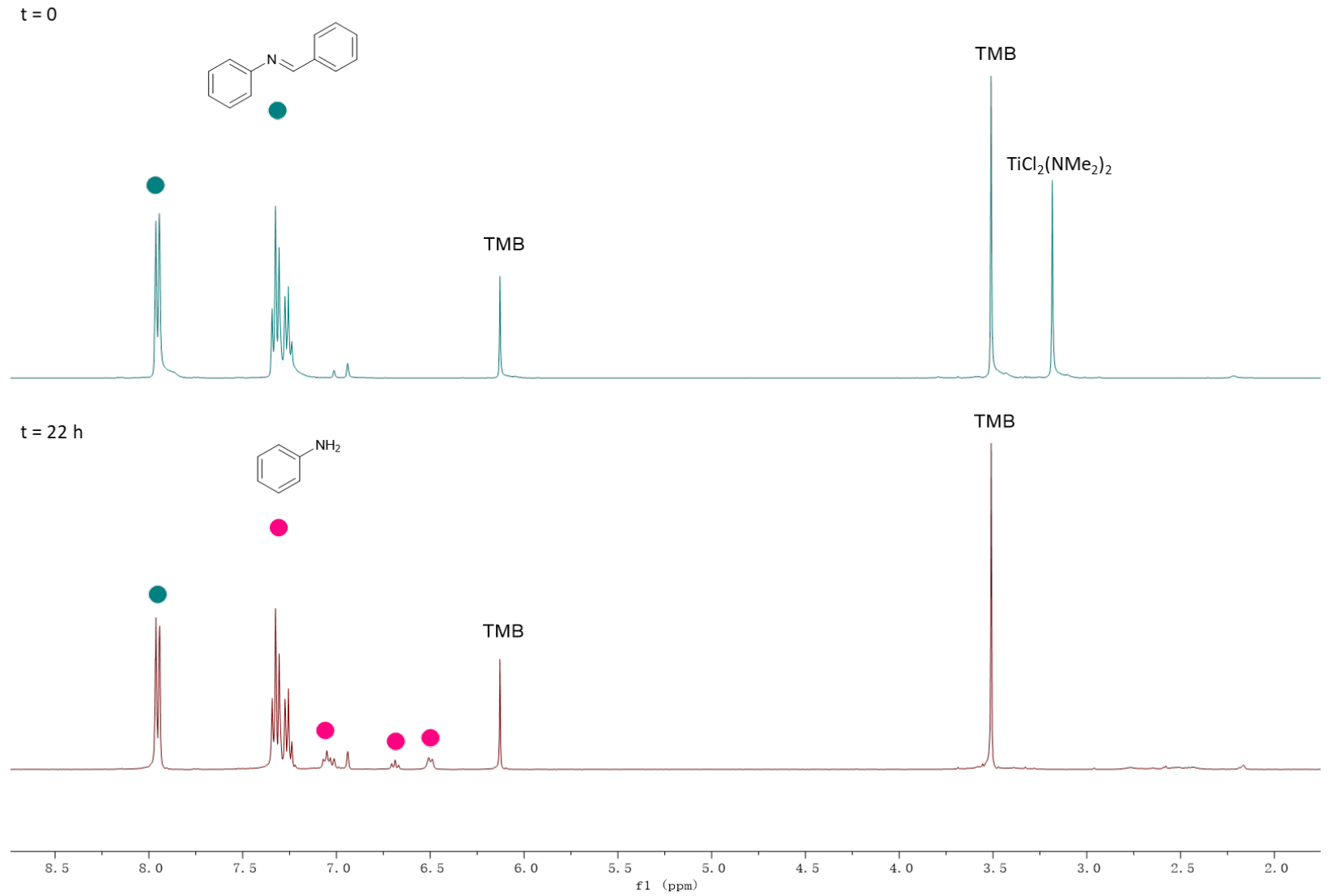

Figure S18. Stacked ${ }^{1} \mathrm{H}$ NMR spectra of $\mathrm{TiCl}_{2}\left(\mathrm{NMe}_{2}\right)_{2}$-catalyzed transfer hydrogenation of azobenzene in $\mathrm{C}_{6} \mathrm{D}_{5} \mathrm{Br}$. Top: $\mathrm{t}=0$. Bottom: $\mathrm{t}=22 \mathrm{~h}$. 


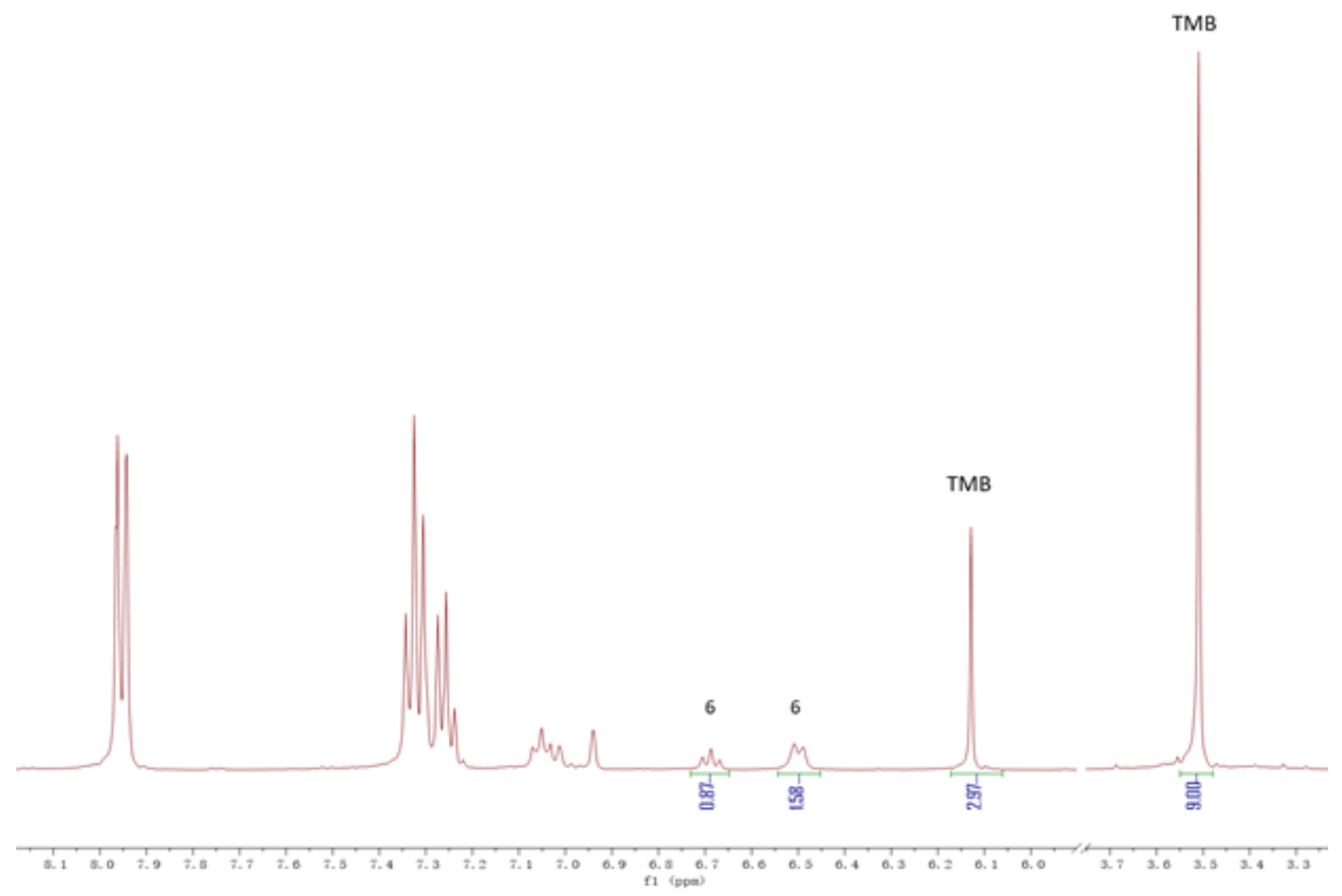

Figure S19. $t=22 \mathrm{~h}{ }^{1} \mathrm{H}$ NMR spectrum of $\mathrm{TiCl}_{2}\left(\mathrm{NMe}_{2}\right)_{2}$-catalyzed transfer hydrogenation of azobenzene in $\mathrm{C}_{6} \mathrm{D}_{5} \mathrm{Br}$ for yield calculation. The consumption of $\mathrm{PhNNPh}$ was $12.7 \%$. 
H/D Scrambling Study

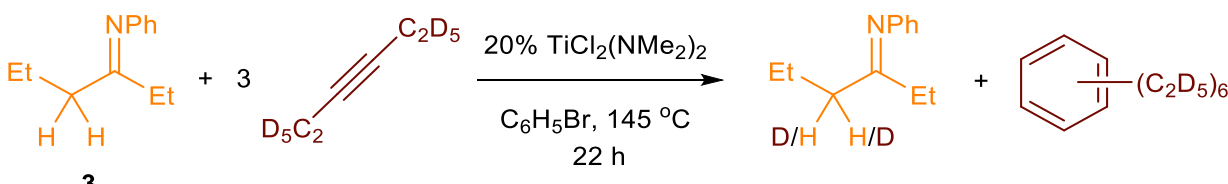

$\mathrm{TiCl}_{2}\left(\mathrm{NMe}_{2}\right)_{2}\left(4.1 \mathrm{mg}, 0.020 \mathrm{mmol}, 0.2\right.$ equiv), 3 ( $17.5 \mathrm{mg}, 0.1 \mathrm{mmol}, 1$ equiv), 3-hexyne- $d_{10}(27.7 \mathrm{mg}, 0.3 \mathrm{mmol}, 3$ equiv), 1,3,5-trimethoxybenzene ( $5.0 \mathrm{mg}, 0.03 \mathrm{mmol}, 0.3$ equiv, ${ }^{1} \mathrm{H}$ NMR internal standard), $\mathrm{C}_{6} \mathrm{D}_{6}(2.5 \mu \mathrm{L}, 0.028 \mathrm{mmol}$, 0.28 equiv, ${ }^{2} \mathrm{H}$ NMR internal standard) and $0.5 \mathrm{~mL}$ of $\mathrm{C}_{6} \mathrm{H}_{5} \mathrm{Br}$ were added to a J-Young NMR tube. The reaction mixture was then sealed and heated in a preheated oil bath at $145^{\circ} \mathrm{C}$ for $22 \mathrm{~h} .{ }^{1} \mathrm{H}$ and ${ }^{2} \mathrm{H}$ NMR spectra were collected before and after heating to monitor the reaction.
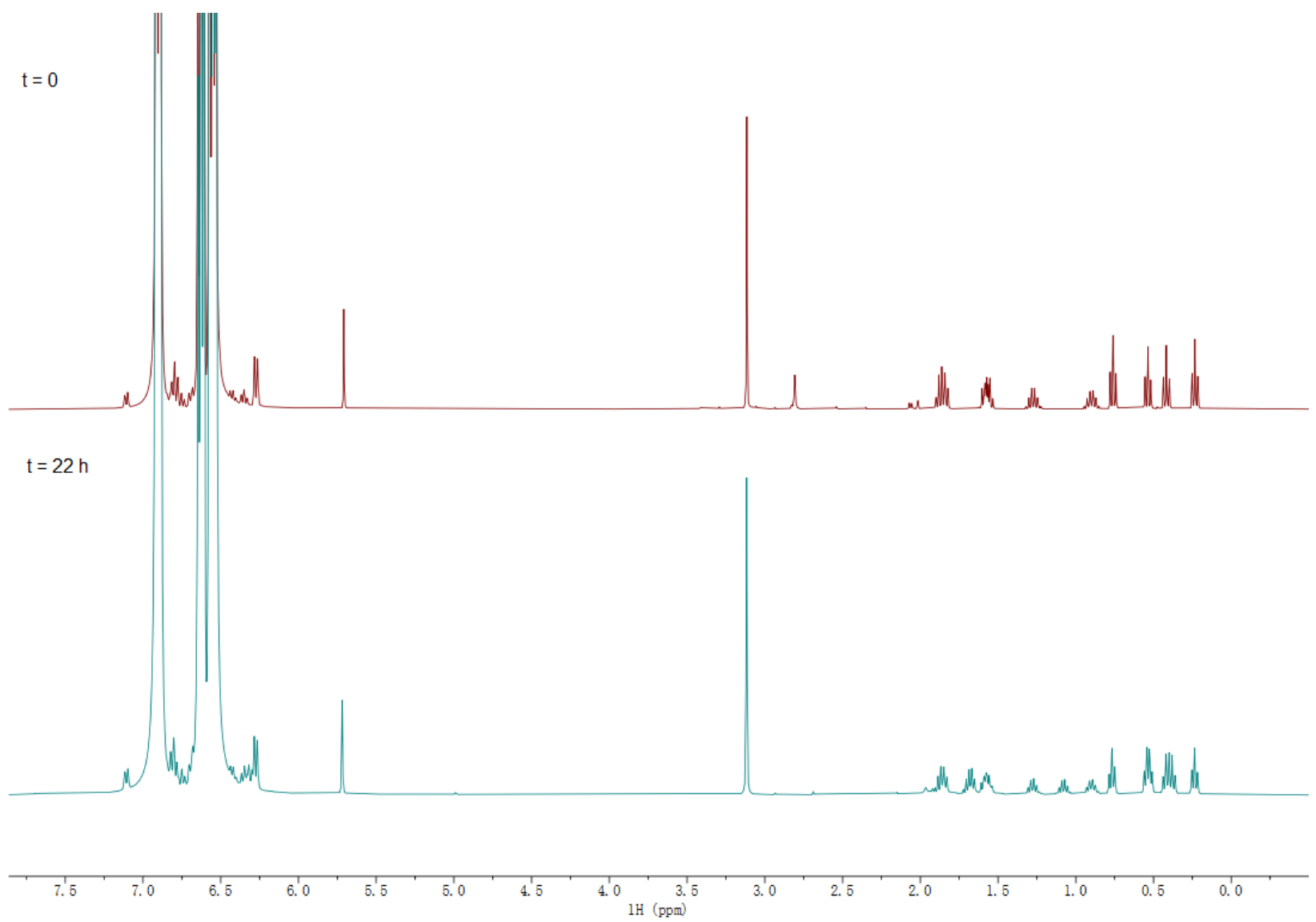

Figure S20. Stacked ${ }^{1} \mathrm{H}$ NMR spectra of $\mathrm{H} / \mathrm{D}$ scrambling experiment of 3 with $\mathrm{TiCl}_{2}\left(\mathrm{NMe}_{2}\right)_{2}$ and 3-hexyne- $d_{10}$ in $\mathrm{C}_{6} \mathrm{H}_{5} \mathrm{Br}$. Top: $\mathrm{t}=0$. Bottom: $\mathrm{t}=22 \mathrm{~h}$. 

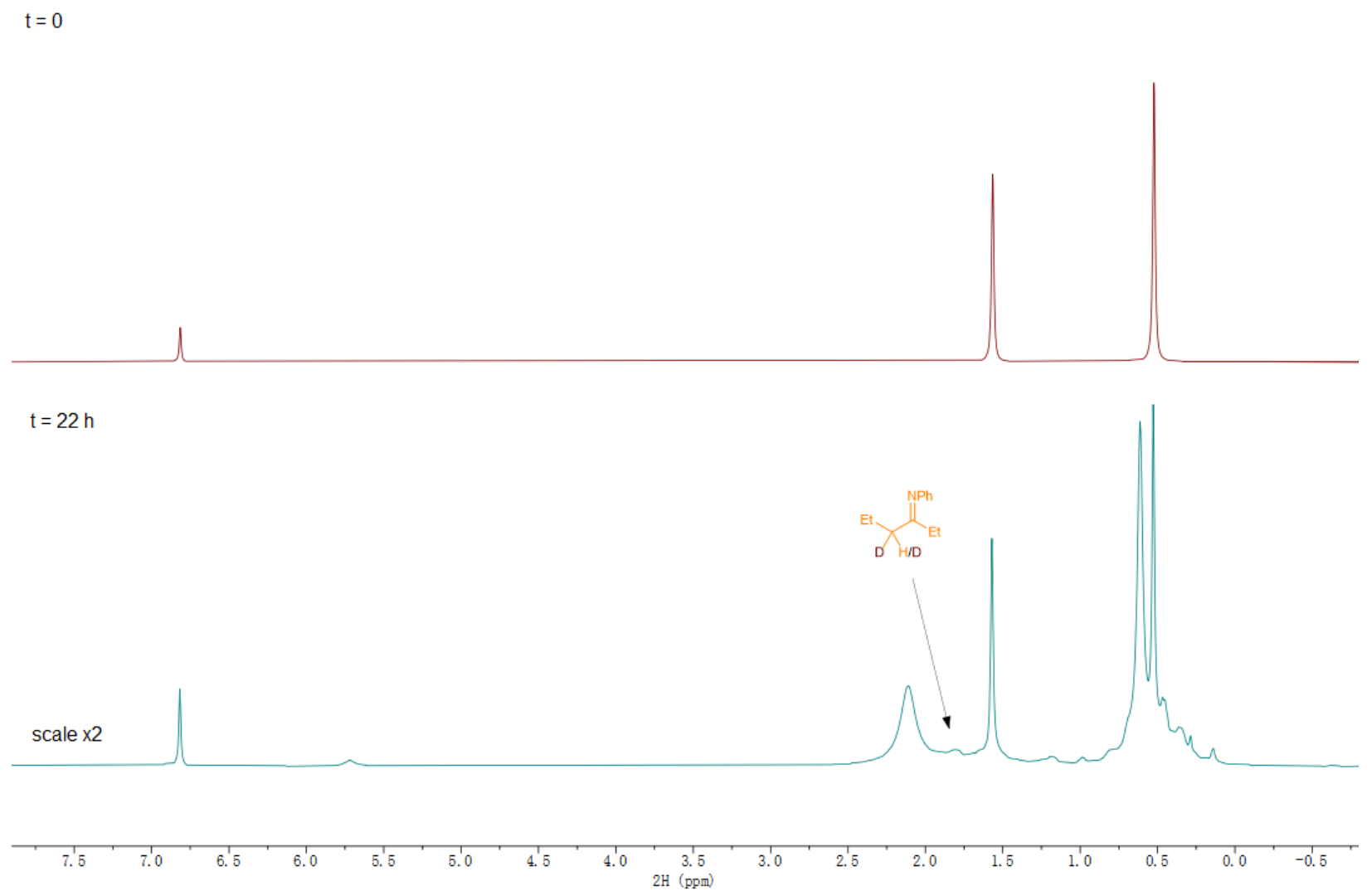

Figure S21. Stacked ${ }^{2} \mathrm{H}$ NMR spectra of H/D scrambling experiment of 3 with $\mathrm{TiCl}_{2}\left(\mathrm{NMe}_{2}\right)_{2}$ and 3-hexyne- $d_{10}$ in $\mathrm{C}_{6} \mathrm{H}_{5} \mathrm{Br}$. Top: $\mathrm{t}=0$. Bottom: $\mathrm{t}=22 \mathrm{~h}$. 
Plausible Mechanism of Transfer Hydrogenation of 4 to Azobenzene

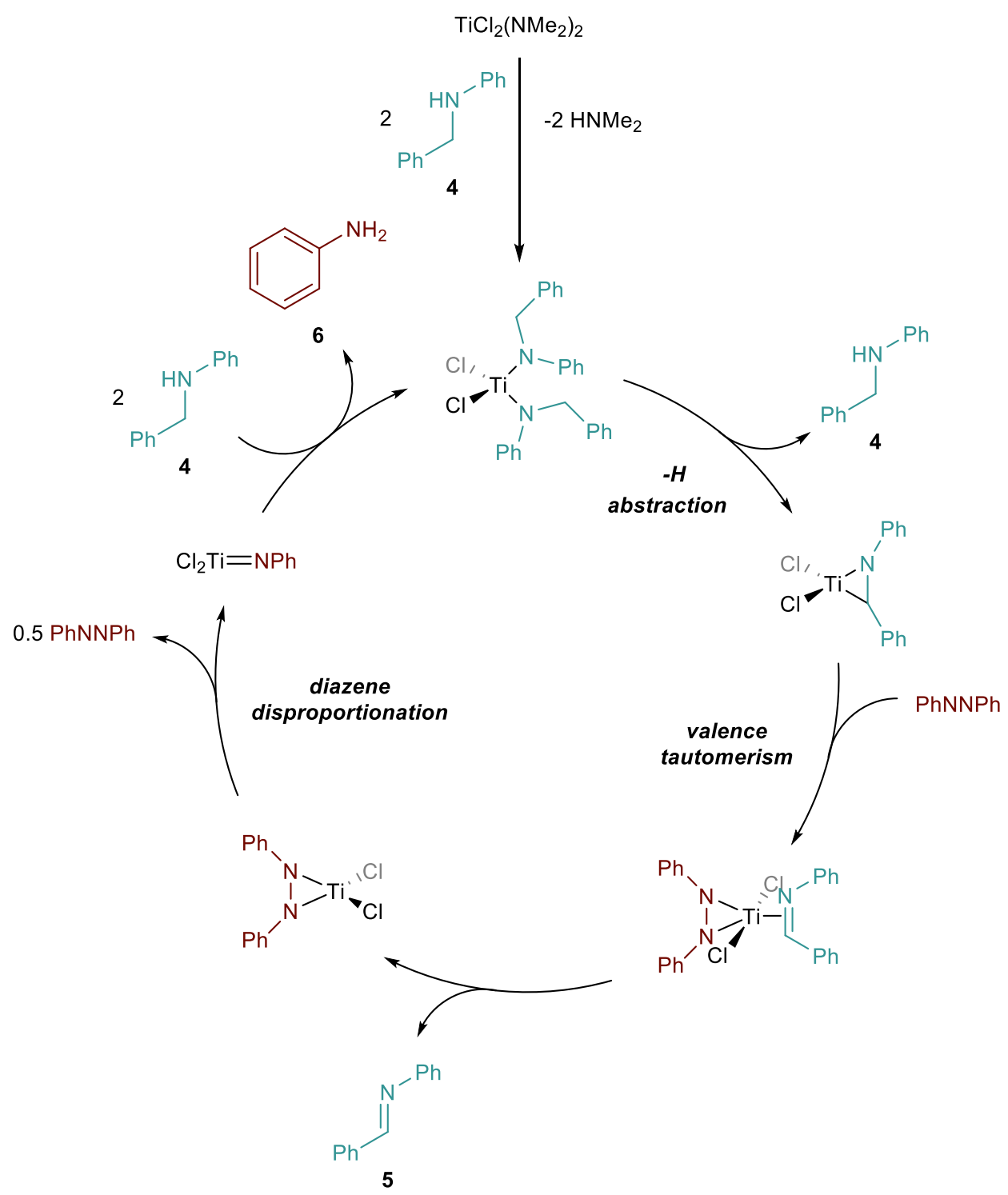

Figure S22. Plausible mechanism of transfer hydrogenation of $\mathbf{4}$ to azobenzene. 
Metal Amide Scope for Cyclotrimerization of 3-Hexyne

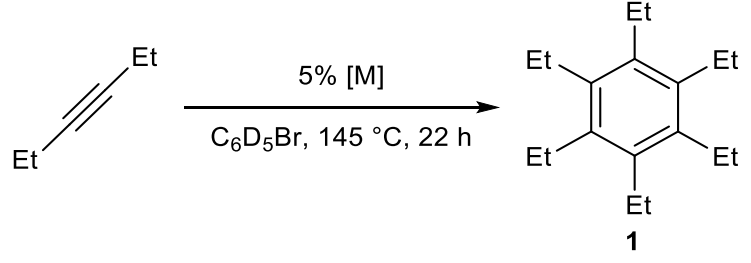

Metal amide ( $0.015 \mathrm{mmol}, 0.05$ equiv), 3-hexyne ( $24.6 \mathrm{mg}, 0.3 \mathrm{mmol}, 1$ equiv), 1,3,5-trimethoxybenzene ( $5.0 \mathrm{mg}, 0.03$ mmol, 0.1 equiv, internal standard) and $0.5 \mathrm{~mL}$ of $\mathrm{C}_{6} \mathrm{D}_{5} \mathrm{Br}$ were added to a J-Young NMR tube. The reaction mixture was then sealed and heated in a preheated oil bath at $145^{\circ} \mathrm{C}$ for $22 \mathrm{~h} .{ }^{1} \mathrm{H}$ NMR spectra were collected before and after heating to monitor the reaction.

Table S1. Metal amide scope for cyclotrimerization of 3-hexyne. ${ }^{2}$

\begin{tabular}{ccc}
\hline Entry & {$[\mathrm{M}]$} & Yield \\
\hline 1 & $\mathrm{TiCl}_{2}\left(\mathrm{NMe}_{2}\right)_{2}$ & $58 \%$ \\
2 & $\mathrm{Ti}\left(\mathrm{NMe}_{2}\right)_{4}$ & not found \\
3 & $\mathrm{Zr}\left(\mathrm{NMe}_{2}\right)_{4}$ & not found \\
4 & $\mathrm{~V}\left(\mathrm{NMe}_{2}\right)_{4}$ & not found \\
5 & $\mathrm{Ta}\left(\mathrm{NMe}_{2}\right)_{5}$ & not found \\
6 & $\mathrm{TiCl}_{4}$ & not found \\
\hline${ }^{a}$ Yield determined by NMR. & &
\end{tabular}

${ }^{a}$ Yield determined by NMR. 
Metal Amide Scope for Hydroamination of 3-Hexyne with Azobenzene and 4
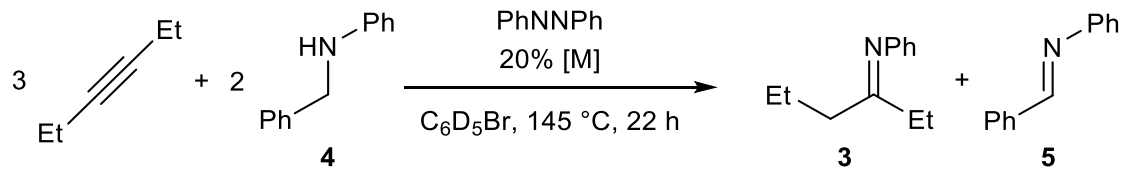

Metal amide ( $0.020 \mathrm{mmol}, 0.2$ equiv), 3-hexyne $(24.6 \mathrm{mg}, 0.3 \mathrm{mmol}, 3$ equiv), azobenzene ( $18.2 \mathrm{mg}, 0.1 \mathrm{mmol}, 1$ equiv), 1,3,5-trimethoxybenzene ( $5.0 \mathrm{mg}, 0.03 \mathrm{mmol}, 0.3$ equiv, internal standard) and $0.5 \mathrm{~mL}$ of $\mathrm{C}_{6} \mathrm{D}_{5} \mathrm{Br}$ were added to a JYoung NMR tube. The reaction mixture was then sealed and heated in a preheated oil bath at $145^{\circ} \mathrm{C}$ for $22 \mathrm{~h} .{ }^{1} \mathrm{H} \mathrm{NMR}$ spectra were collected before and after heating to monitor the reaction.

Table S2. Metal amide scope for hydroamination of 3-hexyne with azobenzene and $4 .^{a}$

\begin{tabular}{cccccc}
\hline Entry & {$[\mathrm{M}]$} & Amount of 3 (mmol) & Yield of 3 & Amount of 5 (mmol) & Yield of 5 \\
\hline 1 & $\mathrm{TiCl}_{2}\left(\mathrm{NMe}_{2}\right)_{2}$ & 0.182 & $91 \%$ & 0.090 & $45 \%$ \\
2 & $\mathrm{Ti}\left(\mathrm{NMe}_{2}\right)_{4}$ & 0.042 & $21 \%$ & 0.016 & $8 \%$ \\
3 & $\mathrm{Zr}\left(\mathrm{NMe}_{2}\right)_{4}$ & not found & n.a. & 0.004 & $2 \%$ \\
4 & $\mathrm{~V}\left(\mathrm{NMe}_{2}\right)_{4}$ & 0.006 & $3 \%$ & 0.028 & $14 \%$ \\
5 & $\mathrm{Ta}\left(\mathrm{NMe}_{2}\right)_{5}$ & 0.005 & $3 \%$ & 0.010 & $5 \%$ \\
6 & $\mathrm{TiCl}_{4}$ & not found & n.a. & 0.006 & $3 \%$ \\
\hline
\end{tabular}

${ }^{2}$ Yield determined by NMR. 


\section{References}

(1) Whitesides, G. M.; Ehmann, W. J. Mechanism of Formation of 1,2,3,4-Tetramethylnaphthalene from 2Butyne and Triphenyltris(Tetrahydrofuran) Chromium(III).J.Am. Chem. Soc. 1970, 92 (19), 5625-5640.

(2) Bielefeld, J.; Doye, S. Dimethylamine as a Substrate in Hydroaminoalkylation Reactions. Angew. Chemie Int. Ed.2017, 56(47), 15155-15158.

(3) Bradley, D. C.; Thomas, I. M. 765. Metallo-Organic Compounds Containing Metal-Nitrogen Bonds. Part I. Some Dialkylamino-Derivatives of Titanium and Zirconium. J. Chem. Soc. 1960, 10 (9), 3857-3861.

(4) Benzing, E.; Kornicker, W. Dialkylamido-Titan(IV)-Chloride Und -Alkoholate. Chem. Ber. 1961, 94 (8), 2263-2267.

(5) Petrakis, L. Spectral Line Shapes: Gaussian and Lorentzian Functions in Magnetic Resonance. J. Chem. Educ. 1967, 44 (8), 432.

(6) Brown, D. W.; Floyd, A. J.; Sainsbury, M. Organic Spectroscopy; John Wiley \& Sons Inc, 1988. 